\title{
CAVIOMORPHS (MAMMALIA, RODENTIA) FROM THE HOLOCENE OF RIO GRANDE DO SUL STATE, BRAZIL: SYSTEMATICS AND PALEOENVIRONMENTAL CONTEXT
}

\author{
PATRÍCIAHADLER \\ Museu de Ciências Naturais, Fundação Zoobotânica do Rio Grande do Sul, Av. Dr. Salvador França, 1427, 90690-000, \\ Porto Alegre, RS, Brazil.hadlerpa@gmail.com
}

DIEGO H. VERZI

División Zoología Vertebrados, Museo de La Plata, Paseo del Bosque s/n, B1900FWA, La Plata, Argentina. dverzi@fcnym.unlp.edu.ar

\section{MARIA GUIOMAR VUCETICH}

División Paleontología Vertebrados, Museo de La Plata, Paseo del Bosque s/n, B1900FWA, La Plata, Argentina. vucetich@fcnym.unlp.edu.ar

\section{JORGE FERIGOLO \& ANA MARIA RIBEIRO}

Museu de Ciências Naturais, Fundação Zoobotânica do Rio Grande do Sul, Av. Dr. Salvador França, 1427, 90690-000, Porto Alegre, RS, Brazil.jorge.ferigolo@fzb.rs.gov.br; ana.ribeiro@fzzb.rs.gov.br

\begin{abstract}
The caviomorph rodents are scarcely known from the Quaternary record of Rio Grande do Sul State, Brazil. This work deals with caviomorphs from two sites, with datings including the Early to Late Holocene. The taxa recorded were: Cavia sp., C. aperea, C. magna, Ctenomys sp., Phyllomys sp., Myocastor coypus, Euryzygomatomys mordax, Dicolpomys fossor, the last two of which are extinct. A new fossil species, Clyomys riograndensis sp.nov. is also described. The stratigraphic distribution of these taxa allows us to suggest a slow and gradual climatic change during the Holocene and a mosaic environment with grasslands and gallery forests, which is indicated by the presence of fossorial animals that typify open areas, coexisting with taxa of forested areas.
\end{abstract}

Key words: Caviidae, Ctenomyidae, Echimyidae, Holocene, palaeoenvironment, Rio Grande do Sul.

RESUMO - Os roedores caviomorfos são pouco conhecidos no registro do Quaternário do Rio Grande do Sul, Brasil. Este trabalho trata dos caviomorfos oriundos de dois sítios, com datações abrangendo do Holoceno inicial ao final. Regitrou-se os táxons: Cavia sp., C. aperea, C. magna, Ctenomys sp., Phyllomys sp., Myocastor coypus, Euryzygomatomys mordax, Dicolpomys fossor, sendo os dois últimos extintos. Descreveu-se também uma nova espécie fóssil, Clyomys riograndensis sp.nov. A distribuição estratigráfica dos táxons sugere uma mudança climática lenta e gradual durante o Holoceno e um ambiente em mosaico, com campos e florestas de galeria, indicado pela presença de animais fossoriais típicos de áreas abertas coexistindo com táxons de áreas florestadas.

Palavras-chave: Caviidae, Ctenomyidae, Echimyidae, Holocene, paleoambiente, Rio Grande do Sul.

\section{INTRODUCTION}

Currently, Rodentia is the largest mammalian Order in number of species among mammals, and the Suborder Hystricomorpha includes more than 160 extinct and living genera distributed in at least 13 South American families ("caviomorphs"; see McKenna \& Bell, 1997; Woods \& Kilpatrick, 2005). This group is first recorded in South America in the Early Oligocene (Tinguirirican South American Land Mammal Age - SALMA-; Flynn et al., 2003), and by the Late Oligocene (Deseadan SALMA) they had already experienced a wide adaptive radiation (Vucetich et al., 1999).
In the Pleistocene, caviomorphs have a noteworthy record in Argentina and Bolivia (e.g., Hoffstetter, 1963; Frailey et al., 1980; Marshall \& Sempere, 1991; Werdelin, 1991; Vucetich et al., 1997; Vucetich \& Verzi, 2002; Verzi et al., 2002); however, they are scarcely known in the Brazilian Subregion (Vucetich et al., 1999). For the Quaternary of Brazil, they are known for the states of Minas Gerais (Lund, 1839a,b; 1840a,b; Winge, 1888; Souza-Cunha \& Guimarães, 1978; Souza-Cunha \& Magalhães, 1986; Emmons \& Vucetich, 1998), São Paulo (Ameghino, 1907; Lino et al., 1979; Barros-Barreto et al., 1982; Castro \& Langer, 2005), Espírito Santo (Paula-Couto, 1978), Bahia (Cartelle \& Lessa, 1989), Rio Grande do Norte (Oliveira 
et al., 1985), Piauí (Guérin, 1991), Pará (Toledo et al., 1999 a,b; Moraes-Santos et al., 1999), Goiás (Salles et al., 1999), Mato Grosso do Sul (Salles et al., 2006), and Rio Grande do Sul (e.g., Oliveira, 1992; Rodrigues \& Ferigolo, 2004). Most of these Brazilian records are from caves, with little or no dating, and in some cases with only tentative identification. Auler $e t$ al. (2006) assigned the assemblages of cave deposits in Minas Gerais and Bahia to Middle Pleistocene $( \pm 350,000$ years) to Early Holocene.

During the last years, archaeological excavations in Rio Grande do Sul recovered assemblages of small-sized mammals, with a large number of specimens, excellent stratigraphic control and $\mathrm{C}^{14}$ datings (Mentz-Ribeiro \& Ribeiro, 1999; Dias \& Jacobus, 2003). The caviomorph assemblages from two of these archaeological localities, encompassing a large part of the Holocene, are here reported. The goal of this contribution is increasing the knowledge of the diversity of Quaternary caviomorphs of southern Brazil, and its palaeoenvironmental context.

\section{MATERIAL AND METHODS}

The material studied constituted more than 400 skull and mandible fragments found during the excavation, by sieving or after by manual selection with the aid of a binocular magnifier among the sieved sediments. The material from Garivaldino site is deposited in the UNISC, and that from Sangão site is at MARSUL. The excavations at the Garivaldino site were performed at arbitrary levels at $10 \mathrm{~cm}$ intervals, comprising twenty-three levels (Dias \& Jacobus, 2003), and at the Sangão site at $5 \mathrm{~cm}$ intervals for a total of thirteen arbitrary levels (Dias, 2003). At Garivaldino site we had access to material from the grids $\mathrm{A} / 6, \mathrm{~B} / 5, \mathrm{C} / 6$, and $\mathrm{D} / 6$; at Sangão site the reported material comes from grids $\mathrm{D} / 13, \mathrm{E} / 12, \mathrm{E} / 13, \mathrm{~F} / 8$ and $\mathrm{F} / 16$, the ones with largest number of specimens (see details in Mentz-Ribeiro et al., 1989; Dias, 2003).

The specimens received compound number (e.g., 17544); the first one (in this case, 1754) indicates the level into a grid from where it was excavated, according to the institutional catalogue numeration for levels and grids. The second number (in this case, 4) indicates the specimen itself, and obeys a sequencial order into a level of a grid.

The material was compared with recent specimens (see Appendix) from scientific collections. Original samples and illustrations of species from Lagoa Santa (Minas Gerais), deposited in ZMUC, were also examined. Bone nomenclature follows Woods \& Howland (1979), and dental structures follow Contreras (1964) and Emmons \& Vucetich (1998). Measurements were taken according to Patton \& Rogers (1983), Vucetich et al. (1997), Leite (2003), and Iack-Ximenes et al. (2005). For the taxonomy of families and subfamilies, conservative criteria have been followed (Woods \& Kilpatrick, 2005; but see e.g. Galewsky et al., 2005). In the examined material section for each species the catalog number is followed by a brief description of the material; the grid; and the level.

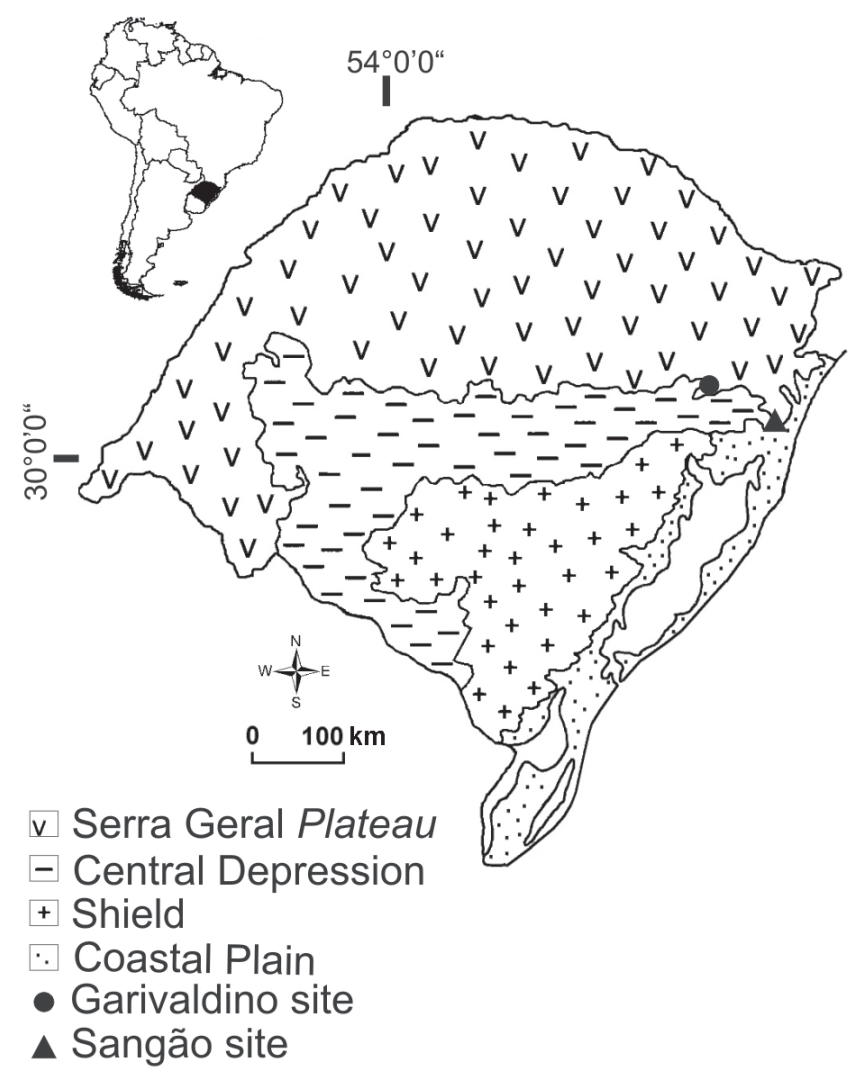

Figure 1. Geomorphologic scheme of Rio Grande do Sul State (Brazil), showing the location of the studied sites.

Institutional abbreviations. MARSUL, Museu Arqueológico do Rio Grande do Sul, Taquara; MCN-M, mastozoologia, Museu de Ciências Naturais da FZBRS, Porto Alegre; MLP, Museo de La Plata, La Plata; MN, Museu Nacional, Rio de Janeiro; MZUSP, Museu de Zoologia da Universidade de São Paulo, São Paulo; UNISC, Centro de Ensino e Pesquisas Arqueológicas da Universidade de Santa Cruz do Sul, Santa Cruz do Sul; ZMUC, Zoological Museum of the University of Copenhagen, Copenhagen.

Anatomical abbreviations. AP, anteroposterior length; AW, anterior width; IFL, incisive foramen length; IFW, incisive foramen width; LDL, lower diastema length; MD, mandible height; n, sample size; PW, posterior width; SD, standard deviation; UDL, upper diastema length; $\bar{X}$, mean average; W, width.

\section{GEOLOGICAL SETTING}

The first locality is Garivaldino site (site RS-TQ-58: Afonso Garivaldino Rodrigues), Municipality of Montenegro, on the boundary between the Central Depression and Serra Geral Plateau (29³4'5" S and 51 $38^{\prime} 44^{\prime \prime}$ W; Figure 1). The second is Sangão site (site RS-S-327: Sangão), Municipality of Santo Antônio da Patrulha, Coastal Plain (29 46' $2^{\prime \prime}$ S and 50 $33^{\circ} 4^{\prime \prime}$ W; Figure 1).

Both sites are rock shelters eroded in the sandstone of the Botucatu Formation (Mentz-Ribeiro \& Ribeiro, 1999; Dias, 2003). The Garivaldino site is $72 \mathrm{~m}$ above sea level, with a 
$21.40 \mathrm{~m}$ opening facing North, is $8.50 \mathrm{~m}$ deep and $8.60 \mathrm{~m}$ high (Mentz-Ribeiro \& Ribeiro, 1999). Sangão site is $52 \mathrm{~m}$ above sea level, its opening being $7 \mathrm{~m}$ above the Sinos River, with a $25 \mathrm{~m}$ opening facing South, and is $10 \mathrm{~m}$ deep and $6 \mathrm{~m}$ high (Dias, 2003). Both sites and shelter plans are shown in MentzRibeiro \& Ribeiro (1999), and Dias (2003).

A taphonomic analysis of the small-mammal fauna from the Garivaldino site suggested that this bone deposit was caused by non-human predators, particularly Strigiforms and/ or Falconiforms birds (Queiroz, 2004). For food remains associated to human occupation [including mammals such as Mazama americana (Erxleben), Ozotocerus sp. Ameghino, Tapirus terrestris (Linneau), Dasypus sp. (Linneau), Cabassous sp. McMurtrie, Cuniculus paca (Linneau), and Myocastor coypus (Molina)] see Mentz-Ribeiro \& Ribeiro (1999), Dias \& Jacobus (2003), and Dias (2004), and for archaeological findings (lithic material, pottery, and pieces made with shells, and bones) see Mentz-Ribeiro et al. (1989), Mentz-Ribeiro \& Ribeiro (1999), and Dias (2003). C14 datings indicate that the sequence integrated for both sites represents the interval Early Holocene (9,400 years BP) - Late Holocene (3,730 years BP; see Table 1$)$.

\section{SYSTEMATICS}

Order RODENTIA Bowdich, 1821

Suborder HYSTRICOMORPHA Brandt, 1855 Infraorder HYSTRICOGNATHI Brandt, 1855

Family CAVIIDAE Fischer de Waldheim, 1817 Cavia Pallas, 1766

Material. UNISC 1515-1; fragment of isolated teeth; A/6; 11. UNISC 1689-1; fragment of edentulous left maxilla; $\mathrm{C} / 6$; 02 . UNISC 1690-6; fragment of right mandible with $\mathrm{m} 2 ; \mathrm{C} / 6$; 03. UNISC 16911 ; fragment of left mandible with dp4-m3; C/6; 04. UNISC 1691-2; fragment of left mandible with m1-2; C/6; 04. UNISC 1691-3; fragment of edentulous right mandible; C/6; 04. UNISC 1692-1; fragment of left mandible with dp4-m3; C/6; 05. UNISC 1694-1; fragment of edentulous right mandible; C/6; 07. UNISC 1696-6; fragment of edentulous right mandible; C/6; 09. UNISC 1698-1; fragment of edentulous right mandible; $\mathrm{C} / 6$; 11 . UNISC 1699-1; fragment of edentulous left mandible; $\mathrm{C} / 6 ; 12$. UNISC 1702-2; fragment of left mandible with broken dp 4 ; $\mathrm{C} / 6 ; 15$. UNISC 17029; fragment of edentulous right mandible; $\mathrm{C} / 6$; 15 . UNISC 1703-11; fragment of edentulous right mandible; $\mathrm{C} / 6$; 16. UNISC 1704-1; fragment of edentulous left mandible; C/6; 17. UNISC 1704-2; fragment of edentulous right maxilla; C/6; 17. UNISC 1705-2; fragment of edentulous right maxilla; $\mathrm{C} / 6 ; 18$. UNISC 1752-10; fragment of edentulous right mandible; $\mathrm{D} / 6$; 02. UNISC 1754-13; fragment of left mandible with dp4-m3; D/6; 04. UNISC 1755-19; fragment of left mandible with m2; D/6; 05. UNISC 1759-9; fragment of edentulous left mandible; D/6; 09. UNISC 1760-3; fragment of right mandible with $\mathrm{m} 1-2 ; \mathrm{D} / 6 ; 10$. UNISC 1761-10; palatal fragment with right DP4-M1 and left DP4-M2, respectively; D/6; 11. UNISC 1761-17; fragment of edentulous right mandible; D/6; 11. UNISC 1761-19; fragment of edentulous right mandible; D/6; 11. UNISC 1768-13; fragment of left mandible with dp4-m3; D/6; 18. UNISC 1769-1; fragment of right mandible with dp4-m1; D/6; 19. UNISC 1770-2; fragment of right mandible with $\mathrm{m} 1 ; \mathrm{D} / 6 ; 20$. UNISC 1771-
3; fragment of edentulous right mandible; D/6; 21. MARSUL 51452; isolated left dp4; D/13; 01. MARSUL 515-50; fragment of left mandible with dp4-m3; D/13; 02. MARSUL 515-51; fragment of right mandible with $\mathrm{m} 1-3 ; \mathrm{D} / 13 ; 02$. MARSUL 516-51; fragment of left mandible with dp4-m2; D/13;03. MARSUL 516-52; fragment of right mandible with $\mathrm{m} 2-\mathrm{m} 3 ; \mathrm{D} / 13 ; 03$. MARSUL $517-$ 50; right mandible with dp4-m3; D/13; 04. MARSUL 518-50; fragment of right mandible with dp4-m2; D/13; 05. MARSUL 51950 ; fragment of edentulous right mandible; D/13; 06. MARSUL 519-53; fragment of right maxilla with broken DP4; D/13; 06. MARSUL 519-54; isolated right $\mathrm{m} 1$ ?; D/13; 06. MARSUL 52051; fragment of right maxilla with broken DP4; D/13; 07. MARSUL 523-50; isolated right $\mathrm{m} 1$ ?; D/13; 10. MARSUL 657-50; fragment of left mandible with dp4-m3; E/12; 02. MARSUL 660-51; fragment of edentulous right maxilla; E/12; 05. MARSUL 662-51; fragment of left maxilla with DP4; E/12; 07. MARSUL 664-18; fragment of right mandible with dp4-m2; E/12;09. MARSUL 667-21; fragment of left mandible with dp4-m3; E/12; 12. MARSUL 669-50; fragment of right mandible with m1-2; E/13; 01. MARSUL 670-16; fragment of left mandible with dp4-m1; E/13;02. MARSUL 671-50; fragment of edentulous left mandible; E/13; 03.MARSUL 671-51; fragment of edentulous left mandible; E/13; 03. MARSUL 672-50; fragment of edentulous left mandible; E/13; 04. MARSUL 673-25; fragment of right mandible with dp4-m3; E/13; 05. MARSUL 673-50; fragment of right mandible with dp4-m1; E/13; 05. MARSUL 6786; fragment of left mandible with dp4-m3; E/13; 08. MARSUL 683-16; fragment of right mandible with broken $\mathrm{m} 2 ; \mathrm{F} / 8 ; 02$. MARSUL 684-12; fragment of left mandible with $\mathrm{m} 1$ and $\mathrm{m} 3 ; \mathrm{F} / 8$; 03. MARSUL 687-23; fragment of left mandible with $\mathrm{m} 1-3 ; \mathrm{F} / 8$; 06. MARSUL 697-4; fragment of left mandible with dp4-m3; F/ 16; 01. MARSUL 697-26; fragment of left mandible with dp4-m3; F/16; 01. MARSUL 698-12; fragment of right mandible with m1-3; F/16; 02. MARSUL 700-50; fragment of right mandible with m2; F/16; 04. MARSUL 701-52; fragment of edentulous right maxilla; F/16; 05. MARSUL 701-54; fragment of edentulous left maxilla; F/ 16; 05. MARSUL 701-55; fragment of edentulous left maxilla; F/ 16; 05. MARSUL 702-5; fragment of left mandible with dp4-m3; F/16; 06. MARSUL 703-51; fragment of left mandible with m2; F/ 16;0 7. MARSUL 703-52; fragment of edentulous right mandible; F/16; 07. MARSUL 703-53; fragment of edentulous left mandible; F/16; 07. MARSUL 704-7; fragment of right mandible with dp4$\mathrm{m} 1 ; \mathrm{F} / 16$; 08. MARSUL 704-28; fragment of left mandible with dp4-m2; F/16;08. MARSUL 705-52; isolated right m3?; F/16;09. MARSUL 707-50; fragment of edentulous right mandible; F/16; 11.

Comments. This genus was already recorded for the Quaternary of São Paulo, Mato Grosso do Sul, Minas Gerais and Rio Grande do Sul states (Souza-Cunha \& Guimarães, 1978; Lino et al., 1979; Mentz-Ribeiro et al., 1989; Salles et al., 2006).

Cavia differs from other genera of the family by having the first prism of the upper and lower molars sublaminar, i.e. very compressed antero-posteriorly; hypoflexus/ hypoflexid with parallel walls and filled with abundant cement; M3 with a short prolongation of the second prism, and no anterior prolongation in p4 (Kraglievich, 1930; Quintana, 1997). In Brazil there are four living species: Cavia aperea Erxleben, C. fulgida Wagler, C. magna Ximenez and C. intermedia Cherem, Olimpio \& Ximenez (Cherem et al., 1999). The identification of species of this genus through fragmentary remains is difficult, especially through incomplete mandibles. Cherem (1999) described interspecific differences only in the angular process; but this process is not preserved in 
specimens of our samples. Thus, in this paper, only undamaged upper teeth could be identified at species level. The remainder of specimens are listed here as Cavia sp.

\section{Cavia aperea Erxleben, 1777 \\ (Figure 2A, Table 1)}

Material. UNISC 1508-3; isolated left DP4; A/6; 04. UNISC 1690-1; fragment of left maxilla with DP4-M2; C/6; 03. MARSUL 701-56; isolated left M3; F/16; 05. MARSUL 705-51; fragment of left maxilla with $\mathrm{M} 1 ; \mathrm{F} / 16 ; 09$.

Comments. These specimens present an external secondary sulcus deeper than in C. magna, and in C. intermedia, but not as deep as in $C$. fulgida, a rectangular shape of the labial end of hypoflexus, the first prism more antero-posteriorly compressed than in C. fulgida, in C. magna, and in $C$. intermedia, and a masseteric tuberosity more anteroposteriorly elongated than in C. magna.

This taxon was previously recorded for the Quaternary of Minas Gerais (Lund, 1839b; 1840a,b; Winge, 1888).

Living Cavia aperea is found in Brazil, Paraguay, Uruguay and northeastern Argentina (Ximenez, 1980), in environments with soils covered by herbaceous vegetation, but also in environments deeply altered by humans (Silva, 1984).

\section{Cavia magna Ximenez, 1980}

(Figure 2B, Table 1)

Material. MARSUL 514-50; fragment of right maxilla with DP4M3; D/13; 01. MARSUL 515-53; fragment of right maxilla with DP4-M1; D/13; 02. MARSUL 521-51; fragment of left maxilla with DP4-M1; D/13; 08. MARSUL 659-5; fragment of left maxilla with DP4-M3; E/12; 04. MARSUL 664-39; palatal fragment with left M1-3 and right DP4-M2; E/12; 09. MARSUL 702-52; fragment of left maxilla with DP4-M3; F/16; 06. MARSUL 704-4; fragment of left maxilla with DP4-M2; F/16; 08.

Comments. These specimens present the first prisms of the
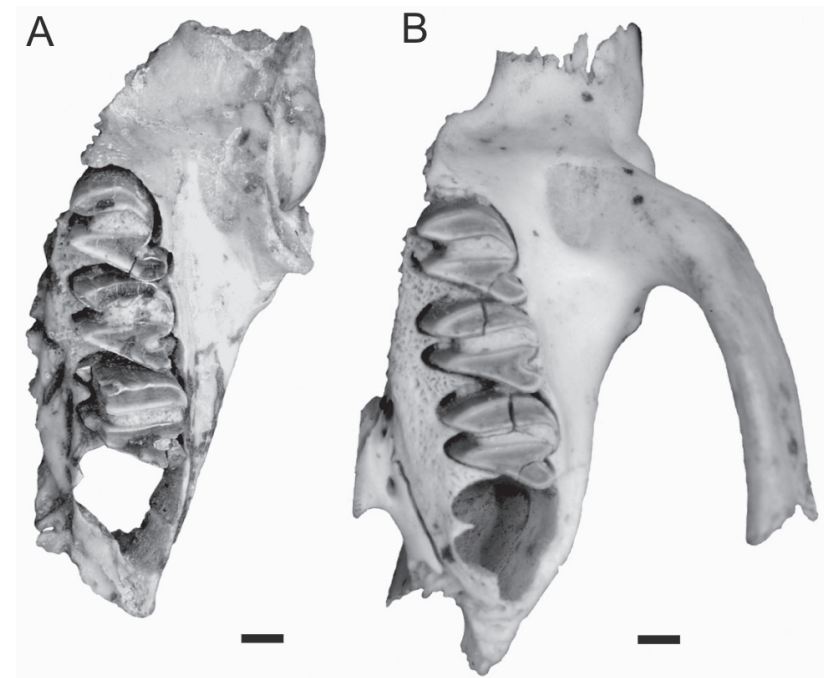

Figure 2. Ventral view of fragment of left maxilla with DP4-M2 of: A, Cavia aperea, UNISC 1690-1; B, Cavia magna, MARSUL 704-4. Scale bars $=1 \mathrm{~mm}$. upper molars more slightly compressed antero-posteriorly than in $C$. aperea and in C. fulgida, but more compressed than in $C$. intermedia, the external secondary sulcus shallower than in $C$. fulgida and $C$. aperea, but deeper than in $C$. intermedia, a rounded shape of the labial end of the hypoflexus, and a circular masseteric tuberosity (Ximenez, 1980; Cherem, 1999).

This species is in Sangão site. It was mentioned by Queiroz (2004) also for the Garivaldino site; however, we were unable to review the material studied by him and we can not identify this species in this site.

The species is living today throughout Uruguay and in the states of Rio Grande do Sul and Santa Catarina (Ximenez, 1980). It is adapted to a semi-aquatic life, inhabiting preferentially the areas of vegetation behind the dunes in restinga habitats, but can also lives in estuaries and next to lagoons (Ximenez, 1980).

Table 1. Occurrence of the taxa in Sangão and Garivaldino sites.

\begin{tabular}{|c|c|c|c|c|c|c|c|c|c|c|}
\hline$\stackrel{\Phi}{\dot{\Phi}}$ & త্ & 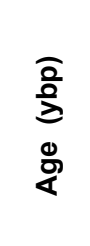 & 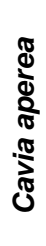 & 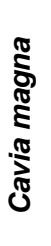 & 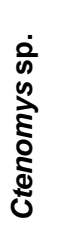 & 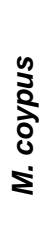 & 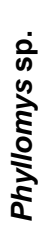 & 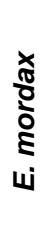 & 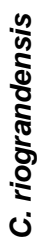 & 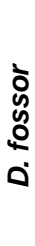 \\
\hline \multirow{13}{*}{ 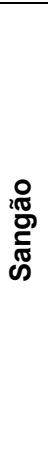 } & 01 & & & $X$ & $X$ & $X$ & $X$ & & & $x$ \\
\hline & 02 & & & $x$ & & & $X$ & & $x$ & $x$ \\
\hline & 03 & & & & $X$ & & & & & $X$ \\
\hline & 04 & 3,730 & & $X$ & $X$ & & $X$ & & & $x$ \\
\hline & 05 & 3,970 & $x$ & & $x$ & & $X$ & & & $x$ \\
\hline & 06 & 4,160 & & $x$ & $x$ & & $X$ & & & $x$ \\
\hline & 07 & & & & & & $X$ & & & $x$ \\
\hline & 08 & 4,710 & & $X$ & $X$ & $x$ & $x$ & & & $x$ \\
\hline & 09 & & $X$ & $x$ & & & $X$ & & $X$ & \\
\hline & 10 & 7,390 & & & & & $X$ & & & $x$ \\
\hline & 11 & & & & $x$ & & $x$ & & & $x$ \\
\hline & 12 & & & & & & & & $x$ & \\
\hline & 13 & 8,800 & & & & & & & & \\
\hline \multirow{23}{*}{$\frac{\circ}{\frac{0}{\frac{0}{0}}}$} & 01 & & & & & & & & & $x$ \\
\hline & 02 & & & & & & $X$ & & & $x$ \\
\hline & 03 & & $x$ & & & & $x$ & $X$ & $x$ & $x$ \\
\hline & 04 & & $X$ & & & & $X$ & $X$ & & $x$ \\
\hline & 05 & & & & & & $x$ & $X$ & $x$ & $x$ \\
\hline & 06 & 7,250 & & & & & $X$ & $X$ & $x$ & $x$ \\
\hline & 07 & & & & & & & $X$ & $x$ & $x$ \\
\hline & 08 & & & & & & $x$ & $X$ & $x$ & $x$ \\
\hline & 09 & & & & & & & $x$ & $x$ & $x$ \\
\hline & 10 & & & & & & & $x$ & $x$ & $x$ \\
\hline & 11 & & & & & & $X$ & $x$ & $x$ & $x$ \\
\hline & 12 & & & & & & $x$ & $X$ & $x$ & $x$ \\
\hline & 13 & & & & & & & $x$ & $x$ & $x$ \\
\hline & 14 & 8,020 & & & & & & & $X$ & $x$ \\
\hline & 15 & & & & & & & $x$ & $x$ & $x$ \\
\hline & 16 & & & & & & & $X$ & $x$ & $x$ \\
\hline & 17 & & & & & & & $X$ & $x$ & $x$ \\
\hline & 18 & 8,290 & & & & & & $X$ & $x$ & $x$ \\
\hline & 19 & & & & & & & $x$ & $x$ & $x$ \\
\hline & 20 & & & & & & & & $x$ & $x$ \\
\hline & 21 & 9,430 & & & & & & $X$ & & \\
\hline & 22 & & & & & & & & & \\
\hline & 23 & & & & & & & & & \\
\hline
\end{tabular}




\section{Family CTENOMYIDAE Lesson, 1842 Ctenomys Blainville, 1826}

Material. MARSUL 660-50; edentulous left maxilla; E/12; 05. MARSUL 661-52; rostrum without teeth; E/12; 06. MARSUL 67352; fragment of right maxilla with DP4; E/13; 05. MARSUL 67647; fragment of edentulous right mandible; E/13; 08. MARSUL 682-35; isolated right lower molar; F/8; 01. MARSUL 684-13; edentulous right mandible; $\mathrm{F} / 8$; 03. MARSUL 685-25; isolated lower molars; F/8; 04. MARSUL 686-35; isolated upper molars; F/8; 05. MARSUL 687-24; right mandible with dp4-m2; F/8; 06. MARSUL 689-25; isolated right lower molar; F/8; 08. MARSUL 701-53; palatal edentulous fragment; F/16; 05. MARSUL 707-4; fragment of edentulous right mandible; F/16; 11.

Comments. The genus Ctenomys has nearly 85 described species (Woods \& Kilpatrick, 2005) in southern South America, from Bolivia, south of Peru, down to Tierra del Fuego (Mares \& Ojeda, 1982; Lessa \& Cook, 1998; Freitas, 2006). In Rio Grande do Sul, four species are currently recognized: Ctenomys torquatus Lichtenstein, which occurs in the southern state portion, in open sandy fields; C. flamarioni Travi in the first line of dunes of the Coastal Plain; C. minutus Nehring, also at the Coastal Plain but more inland (from Santa Catarina State to São Jose do Norte, Rio Grande do Sul); finally, C. lami Freitas in the region of Coxilha das Lombas, extending from Porto Alegre to Lagoa dos Barros (Freitas, 2006; Gonçalves, 2007).

The alpha systematics of Ctenomys species is in flux state because of the difficulties for recognizing taxonomical hierarchy in its variability (see e.g., Reig et al., 1990). The fragmentary preservation of the material precludes specific recognition. However, the available remains are enough for reliable generic assignation.

The genus Ctenomys is adapted to subterranean life, inhabiting galleries, which they excavate, with controlled environmental conditions (e.g., Busch et al., 2000). In Rio Grande do Sul it inhabits mostly sandy open fields and/or dunes (Freitas, 1995).

The genus is first recorded in the Pliocene of northwestern Argentina (Verzi, 2008). For the Quaternary of Brazil, Ctenomys was listed for zooarchaeological localities, including Garivaldino site and for Santa Vitoria do Palmar Municipality, in the Coastal Plain (Mentz-Ribeiro et al., 1989; Buchmann, 2002). However, after the revision of the material ( $\mathrm{PH}$, pers. obs.), this genus could not be confirmed for such localities. Therefore, Ctenomys is here reported only for the Sangão site.

\section{Family ECHIMYIDAE Gray, 1825 Subfamily ECHIMYINAE Gray, 1825 Phyllomys Lund, 1839 Phyllomys sp. (Figure 3, Table 1)}

Material. UNISC 1508-2; fragment of right mandible with m1?; A/ 6; 04. UNISC 1515-2; fragment of left mandible with m1?; A/6; 11. UNISC 1516-2; fragment of right maxilla with DP4; A/6; 12. UNISC 1516-3; fragment of left maxilla with DP4-M1; A/6; 12. UNISC 1689-2; fragment of right maxilla with DP4-M2; C/6; 02. UNISC 1689-3; fragment of left maxilla with M1-2; C/6; 02. UNISC 1689-
4; fragment of left maxilla with M1; C/6; 02. UNISC 1689-7; fragment of right mandible with dp4-m2; C/6; 02. UNISC 1689-8; fragment of left mandible with dp4-m1; C/6; 02. UNISC 1690-2; fragment of right maxilla with DP4; C/6; 03. UNISC 1690-3; fragment of right maxilla with DP4; C/6; 03. UNISC 1690-8; fragment of left mandible with dp4; C/6; 03. UNISC 1690-9; fragment of right mandible with dp4-m2; C/6; 03. UNISC 1690-10; fragment of left mandible with dp4-m2; C/6; 03. UNISC 1690-12; fragment of right mandible with dp4-m1; C/6;03. UNISC 1691-7; fragment of right maxilla with DP4-M1; C/6; 04. UNISC 1692-2; fragment of right mandible with m1-2; C/6;05. UNISC 1693-3; fragment of left mandible with $\mathrm{m} 1$; $\mathrm{C} / 6$; 06. UNISC 1752-11; fragment of left mandible with dp4-m2; D/6; 02. UNISC 1752-12; fragment of left mandible with dp4; D/6;02. UNISC 1753-24; fragment of left maxilla with DP4-M1; D/6; 03. UNISC 1754-4; fragment of left maxilla with DP4; D/6; 04. UNISC 1754-6; fragment of right mandible with dp4-m1; D/6; 04. UNISC 1754-7; fragment of left mandible with dp4-m1; D/6; 04. UNISC 1754-8; fragment of right mandible with $\mathrm{m} 1$; D/6; 04. UNISC 1754-9; fragment of left mandible with dp4; D/6; 04. UNISC 1754-14; fragment of left mandible with dp4; D/6; 04. UNISC 1754-15; fragment of right mandible with dp4; D/6; 04. UNISC 1755-14; fragment of right maxilla with DP4$\mathrm{M} 1$; D/6; 05. UNISC 1755-15; fragment of right maxilla with DP4; D/6; 05. UNISC 1755-18; fragment of left mandible with dp4; D/6; 05. UNISC 1755-20; fragment of right mandible with dp4-m3; D/6; 05. UNISC 1755-22; fragment of left mandible with dp4-m3; D/6; 05. UNISC 1756-10; palatal fragment with both DP4-M3; D/6; 06. UNISC 1756-12; fragment of right maxilla with DP4-M1; D/6; 06. UNISC 1756-13; fragment of right maxilla with DP4-M1; D/6; 06. UNISC 1756-14; fragment of left maxilla with broken DP4; D/6; 06. UNISC 1756-17; fragment of left mandible with $\mathrm{m} 1 ; \mathrm{D} / 6$; 06. UNISC 1756-22; fragment of right mandible with dp4-m2; D/6; 06. UNISC 1758-11; fragment of left mandible with dp4-m1; D/6; 08. UNISC 1758-12; fragment of left mandible with $\mathrm{m} 1 ; \mathrm{D} / 6 ; 08$. MARSUL 514-51; fragment of right mandible with dp4-m1; D/13; 01. MARSUL 515-52; fragment of right maxilla with DP4-M2; D/ 13; 02. MARSUL 519-51; fragment of left mandible with $\mathrm{m} 1$; D/ 13; 06. MARSUL 519-52; fragment of right mandible with dp4$\mathrm{m} 2$; D/13; 06. MARSUL 520-50; fragment of left mandible with dp4-m1; D/13; 07. MARSUL 522-50; fragment of right maxilla with DP4-M2; D/13; 09. MARSUL 656-50; fragment of right mandible with dp4; E/12; 01. MARSUL 657-51; fragment of right maxilla with DP4-M2; E/12; 02. MARSUL 657-52; fragment of right mandible with dp4; E/12; 02. MARSUL 659-50; fragment of right maxilla with DP4-M1; E/12; 04. MARSUL 661-50; fragment of right mandible with m1-2; E/12;06. MARSUL 661-51; palatal fragment with right DP4 and left DP4-M2; E/12; 06. MARSUL 662-50; fragment of left mandible with dp4-m1; E/12; 07. MARSUL 663-51; fragment of left maxilla with DP4-M1; E/12; 08. MARSUL 666-50; fragment of right mandible with m1-2; E/12; 11. MARSUL 673-51; fragment of left mandible with $\mathrm{m} 1$; E/13; 05. MARSUL 674-50; fragment of right mandible with dp4; E/13; 06. MARSUL 674-51; palatal fragment with right M2 and left M1-2; E/13; 06. MARSUL 678-3; fragment of right mandible with dp4-m2; E/13; 10. MARSUL 682-35; fragment of left mandible with dp4-m1; F/ 8; 01. MARSUL 682-36; fragment of left mandible with $\mathrm{m} 1 ; \mathrm{F} / 8$; 01. MARSUL 682-37; fragment of right mandible with dp4-m1; F/ 8; 01. MARSUL 682-39; palatal fragment with right M1-3 and left M2-3; F/8; 01. MARSUL 683-15; fragment of right mandible with $\mathrm{m} 1 ; \mathrm{F} / 8 ; 02$. MARSUL 686-33; fragment of right maxilla with DP4M1; F/8; 05. MARSUL 688-29; fragment of left mandible with dp4-m1; F/8; 07. MARSUL 688-30; fragment of left mandible with 

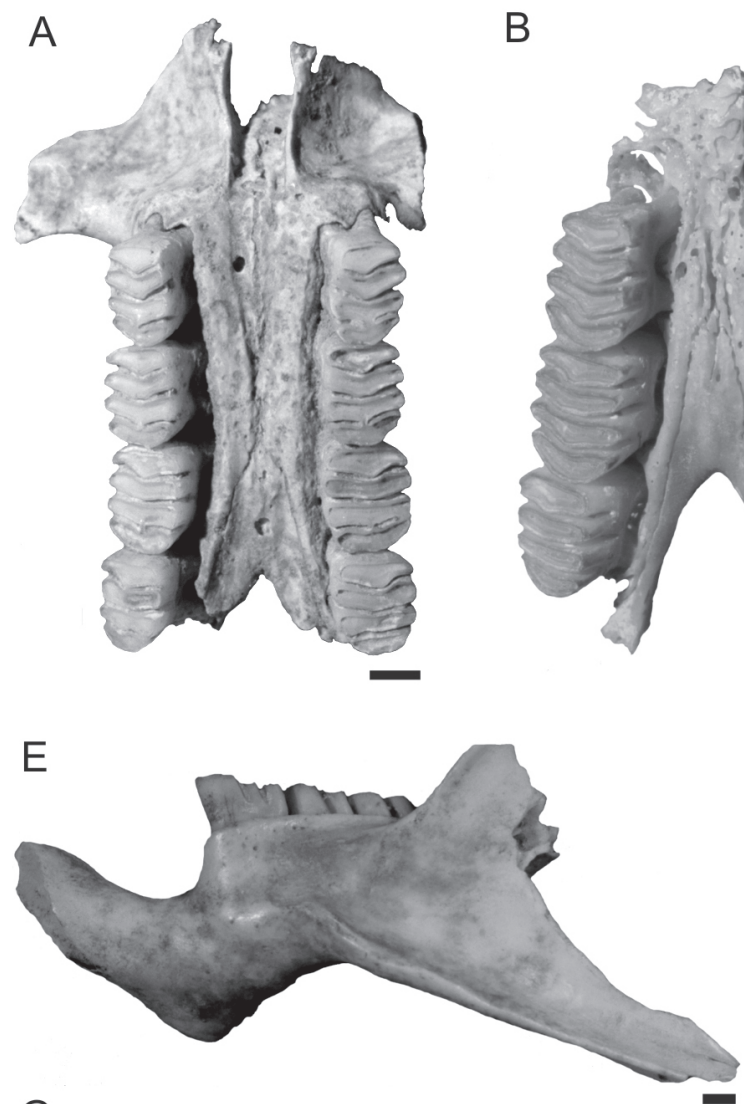

G

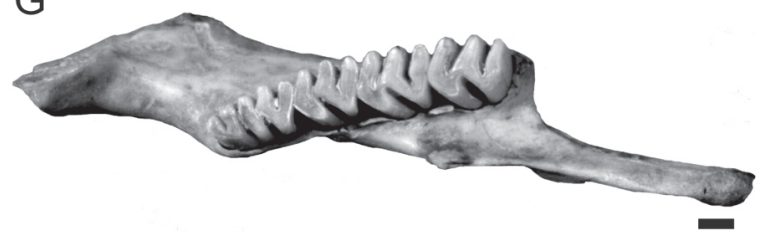

C

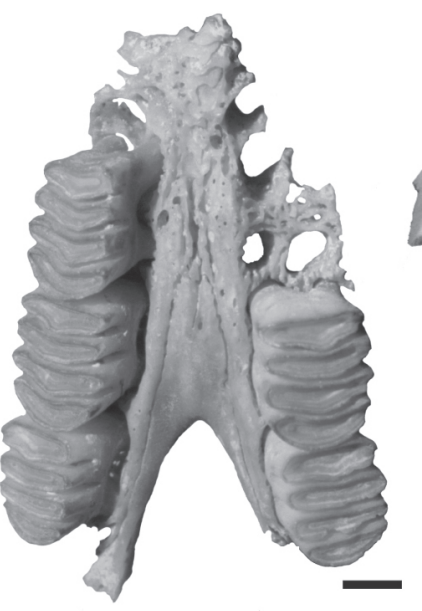

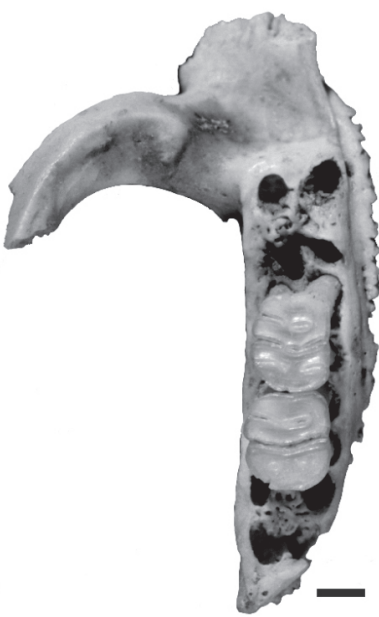

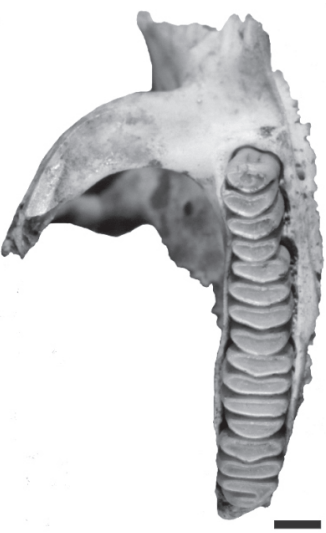

Figure 3. Phyllomys sp. A, UNISC 1756-10, palatal fragment with both DP4-M3 in ventral view; B, MARSUL 682-39, palatal fragment with right M1-3 and left M2-3 in ventral view; C, MARSUL 697-50, fragment of right maxilla with M1-2 in ventral view; D, MARSUL 703-54, fragment of right maxilla with DP4-M3 in ventral view; E, MARSUL 706-50, fragment of left mandible with dp4-m2 in lateral view; F-G, UNISC 1755-22, fragment of left mandible with dp4-m3 in lateral (F) and occlusal (G) views; H, UNISC 1690-10, fragment of left mandible with dp4$\mathrm{m} 2$ in occlusal view. Scale bars $=1 \mathrm{~mm}$.

m1-2; F/8; 07. MARSUL 690-14; fragment of right maxilla with M1; F/8; 09. MARSUL 690-15; fragment of left mandible with dp4-m1; F/8; 09. MARSUL 697-50; fragment of right maxilla with M1-2; F/16; 01. MARSUL 697-51; fragment of right mandible with dp4; F/16; 01. MARSUL 698-50; fragment of right mandible with dp4-m3; F/16; 02. MARSUL 698-52; fragment of left mandible with dp4-m1; F/16; 02. MARSUL 702-51; fragment of left mandible with dp4; F/16; 06. MARSUL 703-50; fragment of right mandible with dp4-m1; F/16; 07. MARSUL 703-54; fragment of right maxilla with DP4-M3; F/16; 07. MARSUL 704-50; fragment of left maxilla with DP4-M2; F/16; 08. MARSUL 706-50; fragment of left mandible with dp4-m2; F/16; 10. MARSUL 706-51; fragment of left mandible with m1-2; F/16; 10. MARSUL 706-52; fragment of right mandible with $\mathrm{m} 1$ ?; F/16; 10. MARSUL 707-52; fragment of left mandible with $\mathrm{m} 1$ ?; F/16; 11.

Comments. Phyllomys is one of the most speciose genera of the Echimyidae. Currently the following species have been recognized: $P$. brasiliensis Lund, $P$. fossilis (Lund), $P$. blainvilli (Jourdan), P. nigrispinus (Wagner), P. unicolor

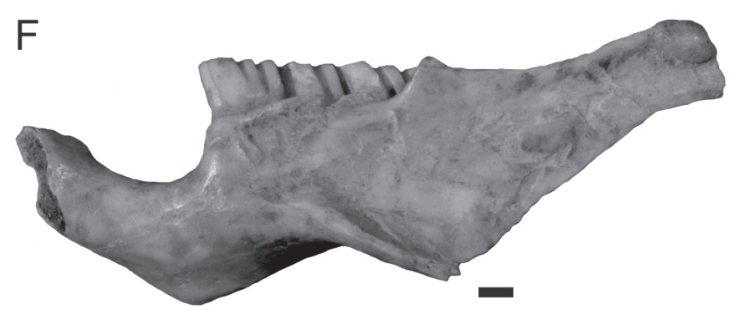

$\mathrm{H}$

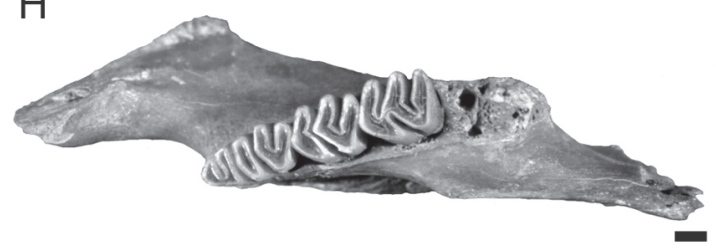

(Wagner), P. dasythrix Hensel, $P$. thomasi (Ihering), P. medius (Thomas), P. lamarum (Thomas), P. kerri (Moojen), P. pattoni Emmons, Leite, Kock \& Costa, $P$. lundi Leite and $P$. mantiqueirensis Leite (Emmons et al., 2002; Leite, 2003).

The studied material is fragmentary but well preserved, with representation of juvenile and adult individuals. This material was assigned to Phyllomys essentially according to the molar morphology. Although Diplomys has a similar dental morphology, this genus has parallel and independent lophids whereas in Phyllomys a connection between lophids results in a sigmoid occlusal figure (Leite, 2003; Emmons, 2005).

Emmons et al. (2002) and Leite (2003) proposed some distinctive features among the species, but these characters proved not to be useful in our sample. Therefore, even though the material of Phyllomys is abundant in the studied sample (more than eighty fragments), it was not possible to recognize species. However, it was possible to restrict the universe of probable species to nine of them: P. brasiliensis, P. blainvilli, 
A

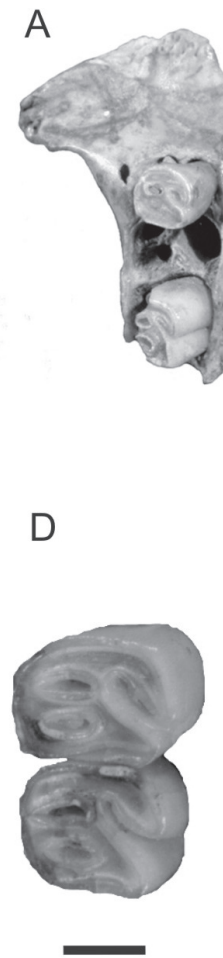

$\mathrm{B}$
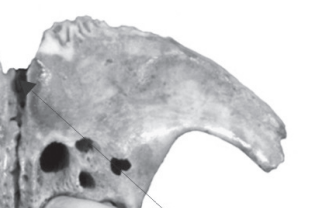

.

posterior portion
of incisive foramen

of incisive foramen

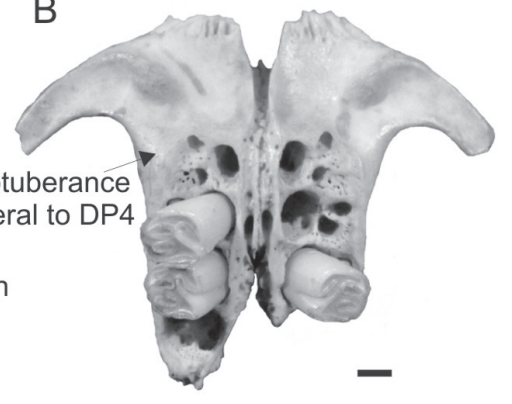

C

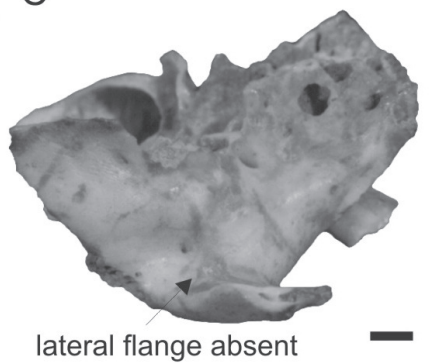

G

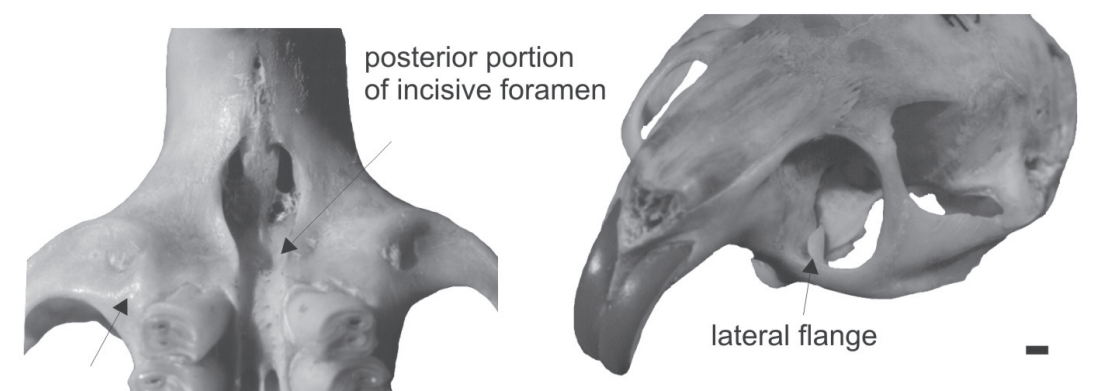

protuberance anterolateral to DP4
$\mathrm{F}$

$\mathrm{H}$
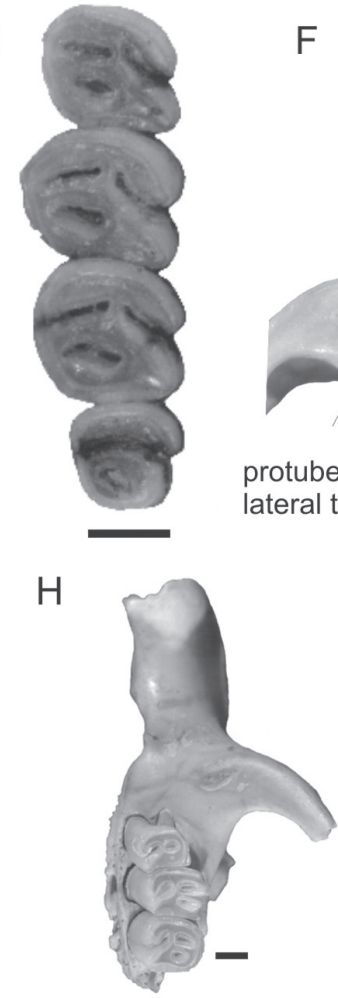

I

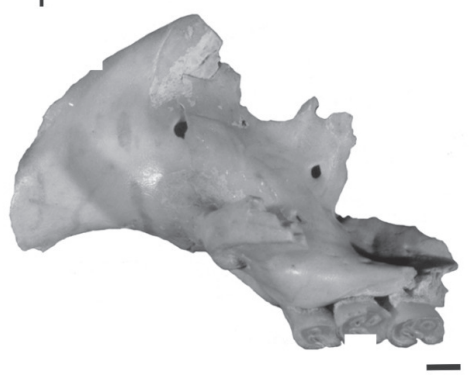

Figure 4. Euryzygomatomys. A-D, E. mordax. A, UNISC 1761-8, palatal fragment with right DP4, and M2 and left M1 in ventral view; B-D, UNISC 1769-17, palatal fragment with right M1-2 and left M2 in ventral (B) and anterolateral (C) views; D, right M1-2 in occlusal view; E-G, E. spinosus; E, MN 4029, right DP4-M3 in occlusal view; F, MCN-M 2364, anterior portion of the skull in ventral view; G, MCN-M 2364, skull in anterolateral view; H-I, E. mordax, UNISC 1768-4, fragment of left rostrum with DP4-M2 in ventral (H) and lateral (I) views. Scale bars $=1 \mathrm{~mm}$.

P. nigrispinus, P. dasythrix, P. medius, P. lamarum, P. kerri, P. pattoni and P. mantiqueirensis. P. fossilis might be recognized through material not comparable with that of our sample, but Emmons et al. (2002) considered it as nomen dubium and possible synonym of $P$. brasiliensis. P. unicolor and $P$. thomasi are two large-sized species, with the length of DP4-M3 greater $(>13 \mathrm{~mm})$ than that of our sample $(\chi=11.27$ $\mathrm{mm} ; \mathrm{SD}=0.05 \mathrm{~mm})$. P. lundi shows M3 with only three laminae, while specimens of our sample have four.

Today Phyllomys includes arboreal species endemic to the Atlantic Forest, occurring from the State of Ceará to Rio Grande do Sul, of which only P. dasythrix and P. medius occur in the last one (Leite, 2003). The only fossil records for Phyllomys were from the Quaternary of the Minas Gerais State (Lund, 1839a,b; 1840a,b; Souza-Cunha \& Guimarães, 1978), and now for Rio Grande do Sul State.
Subfamily EUMYSOPINAE Rusconi, 1935
$\quad$ Euryzygomatomys Goeldi, 1901
Euryzygomatomys mordax (Winge, 1888)

(Figures 4A-D, H-I, 5A-F; Tables 1,2)

Mesomys mordax Winge, 1888:72, pl.8, fig. 7.

Euryzygomatomys mordax (Winge): Paula-Couto, 1946:5.

Type-material. Winge (1888) described this species based on two skulls, skull 1 and 2, belonging to ZMUC (with no catalog numbers), and sketched the most complete one, skull 1 (Winge, 1888:pl.8, fig. 7).

Material. UNISC 1690-5; fragment of right mandible with $\mathrm{m} 1$; C/ 6; 03. UNISC 1691-4; fragment of right mandible with dp4-m2; C/ 6; 04. UNISC 1693-1; fragment of left mandible with $\mathrm{m} 2$; $\mathrm{C} / 6 ; 06$. UNISC 1695-3; fragment of right mandible with $\mathrm{m} 2 ; \mathrm{C} / 6$; 08 . UNISC 1697-1; fragment of right mandible with dp4-m2; C/6; 10. UNISC 1697-5; fragment of left mandible with m1-2; C/6; 10. UNISC 

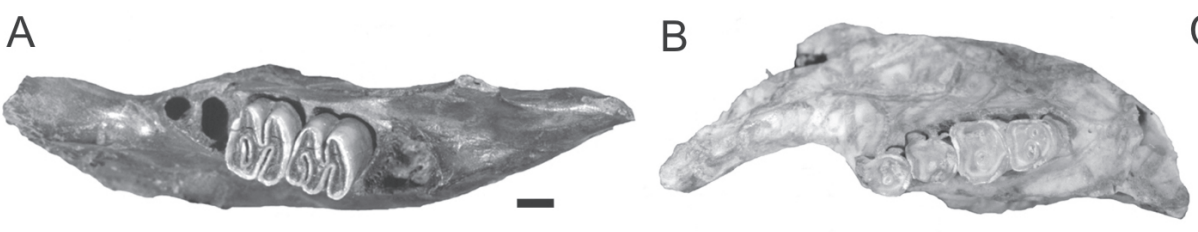

C
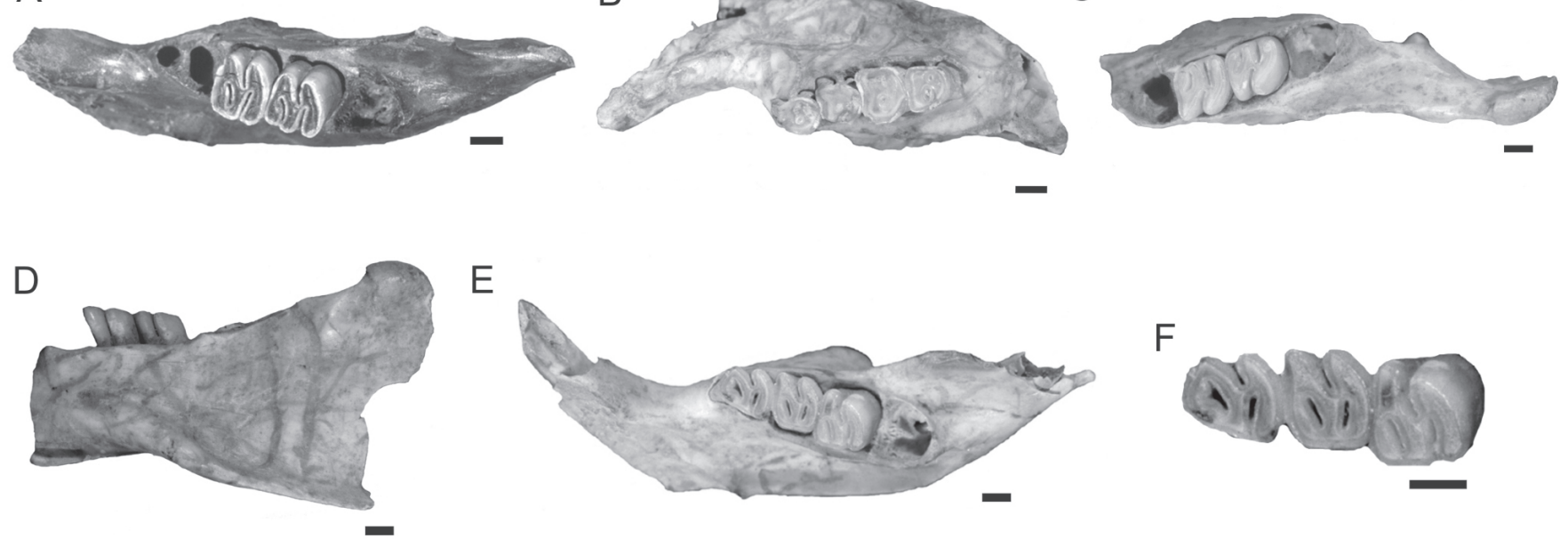

E
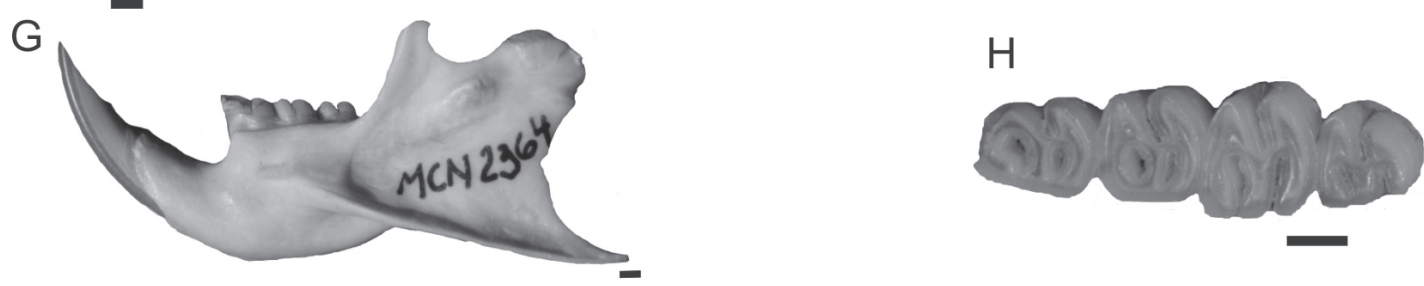

Figure 5. Euryzygomatomys. A-F, E. mordax. A, UNISC 1759-3, fragment of right mandible with m1-2 in occlusal view; B, UNISC 1703-2, fragment of left mandible with dp4-m3 in occlusal view; C-D, UNISC 1755-21, fragment of left mandible with m1-2 in occlusal (C) and lateral (D) views; E-F, UNISC 1691-4, fragment of right mandible with i and dp4-m2 (E) and detail of dp4-m2 (F) both in occlusal view; G-H, E. spinosus, MCN-M 2364, left mandible, (G) lateral view, $\mathbf{H}, \mathrm{dp} 4-\mathrm{m} 3$ in occlusal view. Scale bars $=1 \mathrm{~mm}$.

1697-7; fragment of left maxilla with M1-2; C/6; 10. UNISC 16989; fragment of right mandible with $\mathrm{m} 1-3 ; \mathrm{C} / 6 ; 11$. UNISC 1703-2; fragment of left mandible with dp4-m3; C/6; 16. UNISC 1703-5; fragment of left maxilla with M1-3; C/6; 16. UNISC 1704-3; fragment of right mandible with $\mathrm{m} 1-2 ; \mathrm{C} / 6 ; 17$. UNISC 1704-7; fragment of left mandible with m1-3; C/6;17. UNISC 1754-12; fragment of left mandible with dp4-m2; D/6; 04. UNISC 1755-21; fragment of left mandible with m1-2; D/6; 05. UNISC 1756-15; fragment of right mandible with $\mathrm{m} 1$; D/6; 06. UNISC 1756-19; fragment of right mandible with m1-2; D/6; 06. UNISC 1757- 7; fragment of left maxilla with broken M1; D/6; 07. UNISC 1759-3; fragment of right mandible with m1-2; D/6; 09. UNISC 1761-8; palatal fragment with right DP4, and M2 and left M1; D/6; 11. UNISC 1761-18; fragment of left mandible with m1-2; D/6; 11. UNISC 1762-4; fragment of left mandible with m1-3; D/6; 12. UNISC 1763-6; fragment of left maxilla with M1-2; D/6; 13. UNISC 1763-11; fragment of left maxilla with M2; D/6; 13. UNISC 1765-6; fragment of left maxilla with M1; D/6; 15. UNISC 1766-4; fragment of right maxilla with M1-2; D/6; 16. UNISC 1766-8; fragment of left mandible with $\mathrm{m} 2-3$; D/6; 16. UNISC 1767-3; fragment of right maxilla with DP4-M2; D/6; 17. UNISC 1768-3; fragment of left maxilla with DP4 and M2; D/6; 18. UNISC 1768-4; fragment of left rostrum with DP4-M2; D/6; 18. UNISC 1768-6; fragment of right maxilla with DP4-M1; D/6; 18. UNISC 1769-17; palatal fragment with right M1-2 and left M2; D/6; 19. UNISC 1769-20; fragment of left maxilla with DP4-M1; D/6; 19.

Locality and stratigraphic occurrence. The original material of this extinct species was collected in Lapa da Escrivania Nr. 5, Lagoa Santa, Minas Gerais (Late Pleistocene/Holocene). The new specimens come from Garivaldino site (Holocene). Revised diagnosis. Fossa for the temporal muscle more developed than in Euryzygomatomys spinosus (G. Fischer); upper incisors stronger and more procumbent than in $E$. spinosus; protuberance formed by the bottom of the alveolar sheath of the upper incisor lateral to DP4 (see Winge, 1888: pl.8, fig.7); lateral flange of the canal for infraorbital nerve absent or poorly developed, and posterior portion of incisive foramen narrower than in E. spinosus.

Description. Euryzygomatomys mordax is the largest Eumysopinae here studied (Table 2), but it is smaller than the living Euryzygomatomys spinosus. The premaxilla-maxilla suture is similar to that of E. spinosus. The posterior portion of the incisive foramen is narrower than in E. spinosus; in spite of variation of this character in the latter, it is never as narrow as in E. mordax. The masseteric tuberosity is well developed, from it projecting a well-defined ridge similar to that in E. spinosus, and never so well-defined as in Clyomys. In some individuals, the masseteric tuberosity is more anterior to DP4 when compared to E. spinosus. The base of the alveolar sheath of the upper incisor forms a marked prominence lateral to the DP4, more posterior than in $E$. spinosus (Winge, 1888). The lateral flange of the canal for infraorbital nerve is absent, or it is scarcely developed (UNISC 1768-6).

The original material of $E$. mordax from Lagoa Santa does not include mandibles (Winge, 1888); but taking into account the cranio-mandibular morphological correlation in the living $E$. spinosus, we were able to recognize the mandibles of $E$. mordax in our samples. The mandibles of E. mordax and $E$. spinosus are very similar. The masseteric fossa of some specimens of E. mordax is slightly shallower than in $E$. 
spinosus. The protuberance formed by the bottom of the lower incisor is less defined than in E. spinosus, although this is a variable feature. The mandibular foramen is proximal to the condyle.

The teeth have a quadrangular occlusal outline, especially those with more wear. DP4-M3 are trilophodont. They show reentrant flexi that form elongate fossettes when worn. The deepest part of the hypoflexus turns forward and, in the majority of specimens, it ends anteriorly to the anterior flexus/fossette (para- + mesoflexus/fossette) while in $E$. spinosus it is less extended forward, ending at the level of this fossette. The metafossette is more persistent than that in Clyomys; is transverse, or oblique and labially divergent from the anterior fossette. In E. spinosus the metafossette is generally inclined in the opposite way, being labially convergent with the anterior fossette. The molars show a mure connecting protocone and hypocone, except for the juvenile UNISC 1697-7.

The lower teeth are similar to those of E. spinosus, having a quadrangular occlusal outline, except dp4 which is more rectangular. The hypoflexid is deep and turns posteriorly. The lingual flexids are deep reentrants, forming elongate fossettids. The mesofossettid is turned anteriorly, while the metafossettid is transverse.

Comments. This taxon was described by Winge (1888) as Mesomys mordax. Paula-Couto (1946) assigned the species tentatively to the genus Euryzygomatomys. He did not justify the assignment. This species can be attributed to Euryzygomatomys by the very deep reentrant flexi/flexids, forming elongate fossettes/fossettids and by the anterior fossette and metafossette subequal in size. These two features are differents in Clyomys (Thomas, 1916; Verzi et al., $1995)$. Winge (1888) pointed out that E. mordax presents more conspicuous fossorial adaptation than E. spinosus, such as more procumbent upper incisors and more extended fossae for temporal muscles (see Winge, 1888: pl.7, fig.7).

The living species E. spinosus occurs currently in south and southeast Brazil, northeast Argentina and Paraguay (Woods \& Kilpatrick, 2005). Until now, E. mordax was known only through the materials described by Winge (1888) for the Quaternary of Lagoa Santa. The material here studied is the first record of this species for the Holocene of Rio Grande do Sul, where it was found only in the Garivaldino site.

\section{Dicolpomys Winge, 1888 \\ Dicolpomys fossor Winge, 1888 \\ (Figure 6; Tables 1,2)}

Dicolpomys fossor Winge, 1888:99, pl.8, fig.10.

Type-material. Winge (1888) relied on five mandibles (mandibles 1, 2, 3, 4 and 5) belonging to ZMUC (with no catalog numbers), and sketched (pl.8, fig.10) two of them, mandibles 2 and 3, and the complete molariform series of the mandible 1.

Material. UNISC 1508-1; fragment of left maxilla with M1; A/6; 04. UNISC 1515-3; fragment of right mandible with m2; A/6; 11. UNISC 1562-1; fragment of right mandible with m1-2; B/5; 16.
UNISC 1562-2; fragment of left mandible with m1-2; B/5; 16 . UNISC 1688-1; fragment of right mandible with m1-2; C/6; 01. UNISC 1689-5; fragment of right mandible with dp4-m2; C/6; 02. UNISC 1689-6; fragment of left mandible with $\mathrm{m} 1$; C/6; 02. UNISC 1690-7; fragment of left mandible with dp4-m3; C/6; 03. UNISC 1690-11; fragment of right mandible with dp4-m1; C/6; 03. UNISC 1690-13; fragment of left mandible with m1-2; C/6; 03. UNISC 1691-5; fragment of right mandible with $\mathrm{m} 1 ; \mathrm{C} / 6$; 04. UNISC $1691-$ 6; fragment of right mandible with dp4-m3; C/6; 04. UNISC $1695-$ 2; fragment of left mandible with m1-3; C/6; 08. UNISC 1696-2; fragment of right mandible with dp4-m3; C/6; 09. UNISC 1696-3; fragment of left mandible with $\mathrm{m} 1 ; \mathrm{C} / 6$; 09. UNISC 1696-4; fragment of right mandible with $\mathrm{m} 1$; C/6; 09. UNISC 1696-5; fragment of

Table 2. Measurements (in $\mathrm{mm}$ ) of Euryzygomatomys mordax, Dicolpomys fossor and Clyomys riograndensis sp.nov.

\begin{tabular}{|c|c|c|c|c|c|c|c|}
\hline & \multicolumn{2}{|c|}{ E.mordax } & \multicolumn{2}{|c|}{ D. fossor } & \multicolumn{3}{|c|}{ C. riograndensis } \\
\hline & $(\bar{X} \pm \mathrm{SD})$ & $\mathrm{n}$ & $(\bar{X} \pm \mathrm{SD})$ & $\mathrm{n}$ & \begin{tabular}{|c|} 
UNISC \\
$1768-7$
\end{tabular} & $(\bar{X} \pm \mathrm{SD})$ & $\mathrm{n}$ \\
\hline UDL & $9.55 \pm 0.15$ & 02 & $9.4 \pm 0.2$ & 02 & 9.0 & - & - \\
\hline IFL & - & - & $4.4 \pm 0$ & 01 & 4.0 & - & - \\
\hline IFW & - & - & $1.8 \pm 0$ & 01 & 1.8 & - & - \\
\hline DP4-M3 & - & - & $7.75 \pm 0.11$ & 04 & 7.6 & $8.21 \pm 0.22$ & 08 \\
\hline I1 AP & - & - & - & - & 2.1 & - & - \\
\hline I1 W & - & - & - & - & 1.8 & - & - \\
\hline DP4 AP & $1.96 \pm 0.10$ & 07 & $1.91 \pm 0.20$ & 09 & 2.0 & $2.12 \pm 0.14$ & 26 \\
\hline DP4 AW & $2.13 \pm 0.12$ & 07 & $2.18 \pm 0.18$ & 09 & $2.0^{*}$ & $2.07 \pm 0.10$ & 26 \\
\hline DP4 PW & $1.97 \pm 0.05$ & 07 & $1.88 \pm 0.17$ & 09 & $2.0^{*}$ & $1.92 \pm 0.12$ & 27 \\
\hline M1 AP & $2.13 \pm 0.26$ & 10 & $1.95 \pm 0.20$ & 19 & 2.1 & $2.22 \pm 0.15$ & 33 \\
\hline M1 AW & $2.55 \pm 0.17$ & 10 & $2.22 \pm 0.20$ & 19 & 2.1 & $2.13 \pm 0.17$ & 33 \\
\hline M1 PW & $2.17 \pm 0.23$ & 10 & $1.95 \pm 0.21$ & 19 & 2.0 & $1.85 \pm 0.24$ & 33 \\
\hline M2 AP & $2.26 \pm 0.15$ & 12 & $2.13 \pm 0.18$ & 06 & 2.2 & $2.29 \pm 0.20$ & 10 \\
\hline M2 AW & $2.39 \pm 0.25$ & 12 & $2.32 \pm 0.07$ & 06 & 2.0 & $2.10 \pm 0.16$ & 10 \\
\hline M2 PW & $2.03 \pm 0.25$ & 12 & $2.02 \pm 0.18$ & 06 & 1.8 & $1.69 \pm 0.16$ & 10 \\
\hline M3 AP & $1.9 \pm 0$ & 01 & _- & _- & 1.4 & $1.5 \pm 0.1$ & 02 \\
\hline M3 AW & $1.9 \pm 0$ & 01 & _- & - & 1.4 & $1.26 \pm 0.14$ & 02 \\
\hline M3 PW & $1.12 \pm 0$ & 01 & _- & _- & 0.8 & $0.83 \pm 0.18$ & 02 \\
\hline LDL & $5.19 \pm 0.53$ & 11 & $4.31 \pm 0.37$ & 27 & & $4.54 \pm 0.45$ & 20 \\
\hline MD & $7.16 \pm 0.35$ & 8 & $5.10 \pm 0.44$ & 31 & & $6.14 \pm 0.40$ & 16 \\
\hline Dp4-m3 & $10.71 \pm 0.84$ & 10 & $8.47 \pm 0.49$ & 21 & & $9.19 \pm 0.46$ & 14 \\
\hline i1 AP & $2.3 \pm 0$ & 01 & $1.71 \pm 0.16$ & 07 & & $1.9 \pm 0$ & 01 \\
\hline i1 w & $2.0 \pm 0.1$ & 02 & $1.78 \pm 0.19$ & 06 & & $1.9 \pm 0$ & 01 \\
\hline dp4 AP & $2.53 \pm 0.28$ & 03 & $2.39 \pm 0.16$ & 52 & & $2.41 \pm 0.27$ & 16 \\
\hline dp4 AW & $1.9 \pm 0$ & 02 & $1.54 \pm 0.19$ & 52 & & $1.77 \pm 0.16$ & 16 \\
\hline dp4 PW & $2.1 \pm 0.2$ & 02 & $1.88 \pm 0.13$ & 52 & & $2.13 \pm 0.08$ & 17 \\
\hline m1 AP & $2.36 \pm 0.22$ & 15 & $2.12 \pm 0.15$ & 100 & & $2.19 \pm 0.13$ & 30 \\
\hline m1 AW & $2.41 \pm 0.29$ & 14 & $2.05 \pm 0.19$ & 100 & & $2.25 \pm 0.23$ & 30 \\
\hline $\mathrm{m} 1 \mathrm{PW}$ & $2.41 \pm 0.30$ & 15 & $2.04 \pm 0.17$ & 100 & & $2.26 \pm 0.17$ & 30 \\
\hline m2 AP & $2.42 \pm 0.14$ & 16 & $2.18 \pm 0.19$ & 70 & & $2.24 \pm 0.13$ & 16 \\
\hline m2 AW & $2.33 \pm 0.28$ & 16 & $2.07 \pm 0.33$ & 70 & & $2.26 \pm 0.22$ & 16 \\
\hline m2 PW & $2.48 \pm 0.18$ & 16 & $1.91 \pm 0.33$ & 70 & & $2.18 \pm 0.27$ & 16 \\
\hline m3 AP & $1.91 \pm 0.25$ & 04 & $1.7 \pm 0.2$ & 15 & & $1.76 \pm 0.31$ & 08 \\
\hline m3 AW & $2.11 \pm 0.12$ & 04 & $1.62 \pm 0.38$ & 15 & & $1.77 \pm 0.20$ & 07 \\
\hline m3 PW & $1.7 \pm 0.14$ & 04 & $0.9 \pm 0.40$ & 15 & & $1.3 \pm 0.2$ & 08 \\
\hline
\end{tabular}



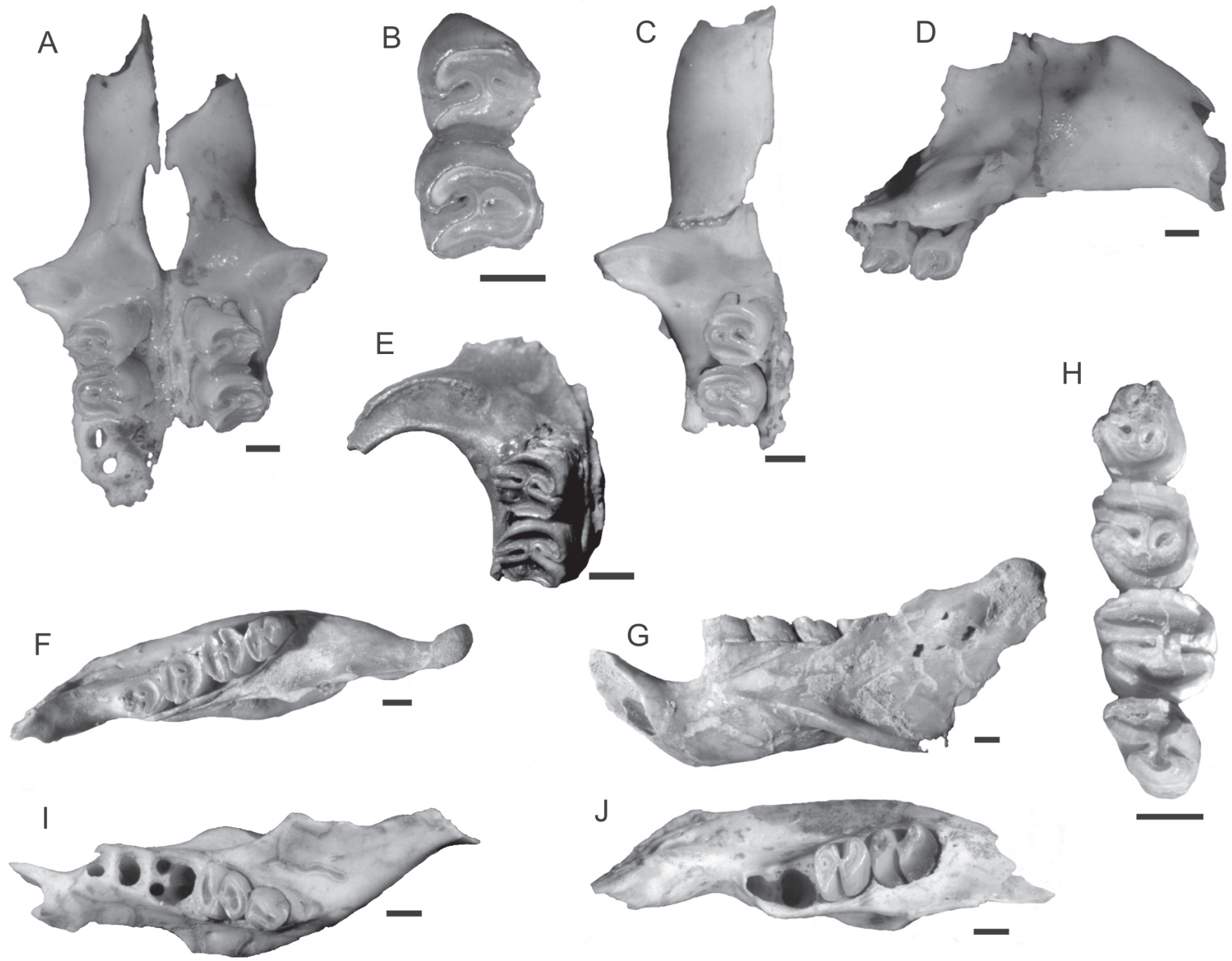

Figure 6. Dicolpomys fossor. A-B, MARSUL 699-51, fragment of rostrum with both DP4-M1, A, ventral view, B, left DP4-M1 in detail; CD, MARSUL 698-53, fragment of right rostrum with DP4-M1 in occlusal (C) and lateral (D) views; E, UNISC 1763-14, fragment of right maxilla with DP4-M1 in occlusal view; F-H, UNISC 1699-3, fragment of left mandible with dp4-m3 in occlusal (F) and lateral (G) views; H, dp4-m3 in detail; I, UNISC 1702-7, fragment of right mandible with m2-3 in occlusal view; J, UNISC 1765-18, fragment of left mandible with m1-2 in occlusal view. Scale bars $=1 \mathrm{~mm}$.

right mandible with $\mathrm{m} 2$; $\mathrm{C} / 6$; 09. UNISC 1697-2; fragment of right mandible with $\mathrm{m} 1 ; \mathrm{C} / 6 ; 10$. UNISC 1697-3; fragment of left mandible with $\mathrm{m} 1 ; \mathrm{C} / 6 ; 10$. UNISC 1697-4; fragment of right mandible with m1-3; C/6; 10. UNISC 1697-6; fragment of left mandible with m12 ; C/6; 10. UNISC 1698-2; fragment of left mandible with m1-2; C/ 6; 11. UNISC 1698-3; fragment of right mandible with $\mathrm{m} 1-2 ; \mathrm{C} / 6$; 11. UNISC 1698-4; fragment of left mandible with m1-2; C/6; 11. UNISC 1698-5; fragment of left mandible with m2-3; C/6; 11. UNISC 1698-6; fragment of left mandible with $\mathrm{m} 1$; C/6; 11. UNISC 1698-11; fragment of left mandible with $\mathrm{m} 2$; C/6; 11 . UNISC 16992 ; fragment of left mandible with $\mathrm{m} 2 ; \mathrm{C} / 6 ; 12$. UNISC 1699-3; fragment of left mandible with dp4-m3; C/6; 12. UNISC 1699-4; fragment of right mandible with dp4-m2; C/6;12. UNISC 1700-3; fragment of left mandible with $\mathrm{m} 1 ; \mathrm{C} / 6 ; 13$. UNISC 1700-4; fragment of left mandible with dp4-m1; C/6; 13. UNISC 1701-4; fragment of right maxilla with M1-2; C/6; 14. UNISC 1701-5; fragment of right mandible with $\mathrm{m} 1 ; \mathrm{C} / 6 ; 14$. UNISC 1702-3; fragment of left mandible with dp4-m1; C/6; 15. UNISC 1702-4; fragment of right mandible with $\mathrm{m} 1 ; \mathrm{C} / 6 ; 15$. UNISC $1702-7$; fragment of right mandible with $\mathrm{m} 2-3$; C/6; 15. UNISC 1702-8; fragment of right mandible with $\mathrm{m} 2$;
C/6; 15. UNISC 1703-6; fragment of right mandible with m1-3; C/ 6; 16. UNISC 1703-9; fragment of left mandible with $\mathrm{m} 1-2$; $\mathrm{C} / 6$; 16. UNISC 1703-10; fragment of left mandible with $\mathrm{m} 1-2 ; \mathrm{C} / 6 ; 16$. UNISC 1703-12; fragment of left mandible with dp4-m2; C/6; 16. UNISC 1704-4; fragment of right mandible with dp4-m2; C/6; 17. UNISC 1704-5; fragment of right mandible with dp4-m1; C/6; 17. UNISC 1704-9; fragment of right mandible with dp4-m2; C/6; 17. UNISC 1706-3; fragment of right mandible with $\mathrm{m} 1$; $\mathrm{C} / 6$; 19. UNISC 1706-4; fragment of left mandible with $\mathrm{m} 1-3 ; \mathrm{C} / 6 ; 19$. UNISC 1706-6; fragment of left mandible with m1-2; C/6; 19. UNISC 1706-8; fragment of right mandible with $\mathrm{m} 1 ; \mathrm{C} / 6$; 19. UNISC $1707-$ 1; fragment of left maxilla with DP4-M2; C/6;20. UNISC 1754-10; fragment of right mandible with $\mathrm{m} 2$ ?; D/6; 04. UNISC 1754-11; fragment of left mandible with dp4-m1; D/6; 04. UNISC 1755-16; fragment of right mandible with m1-2; D/6; 05. UNISC 1755-17; fragment of left mandible with dp4 and $\mathrm{m} 2 ; \mathrm{D} / 6$; 05. UNISC $1756-$ 16; fragment of right mandible with dp4-m3; D/6; 06. UNISC 175618; fragment of right mandible with $\mathrm{m} 1 ; \mathrm{D} / 6 ; 06$. UNISC 1756-20; fragment of right mandible with dp4-m2; D/6; 06. UNISC 1756-23; fragment of right mandible with $\mathrm{m} 1 ; \mathrm{D} / 6 ; 06$. UNISC 1757-5; 
fragment of right maxilla with M2; D/6; 07. UNISC 1757- 6; fragment of left maxilla with M1-2; D/6; 07. UNISC 1757-10; fragment of right mandible with $\mathrm{m} 3$ ?; D/6; 07. UNISC 1757-11; fragment of left mandible with dp4-m1; D/6; 07. UNISC 1757-12; fragment of right mandible with $\mathrm{m} 2$ ?; $\mathrm{D} / 6$; 07. UNISC 1757-13; fragment of right mandible with dp4-m1; D/6; 07. UNISC 1757-14; fragment of left mandible with $\mathrm{m} 1 ; \mathrm{D} / 6 ; 07$. UNISC 1758-7; fragment of right mandible with $\mathrm{m} 1$ ?; D/6; 08. UNISC 1758-9; fragment of right mandible with dp4-m1; D/6; 08. UNISC 1758-10; fragment of right mandible with dp4-m1; D/6;08. UNISC 1759-4; fragment of right mandible with dp4-m1; D/6;09. UNISC 1759-5; fragment of right mandible with dp4-m1; D/6;09. UNISC 1759-6; fragment of left mandible with broken m1; D/6; 09. UNISC 1759-8; fragment of right mandible with dp4; D/6;09. UNISC 1761-12; fragment of right mandible with m1-2; D/6; 11. UNISC 1761-13; fragment of right mandible with dp4-m2; D/6; 11. UNISC 1761-14; fragment of left mandible with dp4-m3; D/6; 11. UNISC 1761-16; fragment of right mandible with $\mathrm{m} 1 ; \mathrm{D} / 6 ; 11$. UNISC 1761-20; fragment of left mandible with $\mathrm{m} 2 ; \mathrm{D} / 6 ; 11$. UNISC 1762-5; fragment of left mandible with dp4-m2; D/6; 12. UNISC 1762-7; fragment of right mandible with dp4-m2; D/6; 12. UNISC 1762-8; fragment of left mandible with $\mathrm{m} 1 ; \mathrm{D} / 6 ; 12$. UNISC 1763-7; fragment of right maxilla with DP4; D/6; 13. UNISC 1763-12; fragment of left maxilla with M12 ; D/6; 13. UNISC 1763-13; fragment of right maxilla with M1-2; $\mathrm{D} / 6$; 13. UNISC 1763-14; fragment of right maxilla with DP4-M1; $\mathrm{D} / 6$; 13. UNISC 1763-15; fragment of right mandible with dp4 and $\mathrm{m} 2$; D/6; 13. UNISC 1763-16; fragment of right mandible with $\mathrm{m} 2$; $\mathrm{D} / 6$; 13. UNISC 1763-17; fragment of right mandible with m2; D/ 6; 13. UNISC 1763-20; fragment of left mandible with m1; D/6; 13. UNISC 1763-21; fragment of right mandible with dp4-m2; D/6; 13. UNISC 1763-22; fragment of right mandible with m1-2; D/6; 13. UNISC 1764-1; Fragment of left maxilla with M1; D/6; 14. UNISC 1764-2; fragment of right mandible with dp4-m2; D/6; 14. UNISC 1764-3; fragment of right mandible with $\mathrm{m} 1-2$; D/6; 14. UNISC 1764-5; fragment of right mandible with dp4-m2; D/6; 14. UNISC 1764-6; fragment of left mandible with dp4-m1; D/6; 14. UNISC 1764-7; fragment of left mandible with $\mathrm{m} 1 ; \mathrm{D} / 6 ; 14$. UNISC $1765-$ 2; fragment of left maxilla with M1; D/6; 15. UNISC 1765-11; fragment of right mandible with $\mathrm{m} 1 ; \mathrm{D} / 6 ; 15$. UNISC 1765-12; fragment of right mandible with $\mathrm{m} 1 ; \mathrm{D} / 6 ; 15$. UNISC 1765-13; fragment of left mandible with dp4; D/6; 15. UNISC 1765-14; fragment of left mandible with $\mathrm{m} 2-3$; D/6; 15. UNISC 1765-17; fragment of left mandible with $\mathrm{m} 1 ; \mathrm{D} / 6 ; 15$. UNISC 1765-18; fragment of left mandible with m1-2; D/6; 15. UNISC 1766-3; fragment of right maxilla with M1; D/6; 16. UNISC 1766-5; fragment of left mandible with dp4; D/6; 16. UNISC 1766-7; fragment of left mandible with dp4; D/6; 16. UNISC 1767-6; fragment of right mandible with m1; D/6; 17. UNISC 1767-7; fragment of left mandible with dp4; D/6; 17. UNISC 1767-8; fragment of right mandible with dp4-m2; D/6; 17. UNISC 1768-8; fragment of left mandible with dp4-m2; D/6; 18. UNISC 1768-10; fragment of right mandible m12 ; D/6; 18. UNISC 1768-12; fragment of right mandible with $\mathrm{m} 1-3$; $\mathrm{D} / 6$; 18. UNISC 1768-14; fragment of right mandible with m2; D/ 6; 18. UNISC 1768-15; fragment of left mandible with $\mathrm{m} 1 ; \mathrm{D} / 6 ; 18$. UNISC 1769-4; fragment of left mandible with m1-2; D/6; 19. UNISC 1769-5; fragment of left mandible with dp4; D/6; 19. UNISC 1769-6; fragment of left mandible with dp4-m1; D/6; 19. UNISC 1769-7; fragment of right mandible with dp4-m2; D/6; 19. UNISC 1769-9; fragment of right mandible with dp4-m3; D/6; 19. UNISC 1769-10; fragment of left mandible with dp4-m1; D/6; 19. UNISC 1769-14; fragment of left mandible with m2; D/6; 19. UNISC 176915 ; fragment of left mandible with dp4-m1; D/6; 19. UNISC 176922 ; fragment of right maxilla with DP4-M1; D/6; 19. UNISC 17701 ; fragment of left mandible with m1-2; D/6; 20. UNISC 1770-3; fragment of right mandible with $\mathrm{m} 1 ; \mathrm{D} / 6 ; 20$. UNISC 1770-5; fragment of left maxilla with M1-2; D/6; 20. UNISC 1770-7; fragment of left mandible with $\mathrm{m} 2 ; \mathrm{D} / 6 ; 20$. MARSUL 516-50; fragment of right mandible with $\mathrm{m} 1 ; \mathrm{D} / 13 ; 03$. MARSUL 520-52; isolated left DP4; D/13; 07. MARSUL 521-50; fragment of left mandible with $\mathrm{m} 2$; D/13;08. MARSUL 656-1; fragment of left mandible with dp4-m1; E/12; 01. MARSUL 656-51; fragment of right mandible with m1-2; E/12; 01. MARSUL 663-50; fragment of left mandible with $\mathrm{m} 2$; E/12; 08. MARSUL 665-50; fragment of left mandible with $\mathrm{m} 1 ; \mathrm{E} / 12 ; 10$. MARSUL 669-51; fragment of left mandible with $\mathrm{m} 1$; E/13; 01. MARSUL 671-52; fragment of right mandible with m1-2; E/13;03. MARSUL 671-53; fragment of right mandible with $\mathrm{m} 1$; E/13; 03. MARSUL 671-54; fragment of right mandible with dp4-m1; E/13; 03. MARSUL 672-51; fragment of right maxilla with DP4; E/13;04. MARSUL 678-50; fragment of left mandible with dp4-m1; E/13; 08. MARSUL 687-21; fragment of left mandible with dp4-m1; F/8; 06. MARSUL 687-22; fragment of left mandible with dp4-m1; F/8; 06. MARSUL 689-24; fragment of right mandible with dp4-m1; F/8; 08. MARSUL 698-51; fragment of right mandible with $\mathrm{m} 2 ; \mathrm{F} / 16$; 02. MARSUL 698-53; fragment of right rostrum with DP4-M1; F/16; 02. MARSUL 699-51; fragment of rostrum with both DP4-M1; F/16; 03. MARSUL 69952; fragment of left maxilla with DP4-M1; F/16; 03. MARSUL 699-53; fragment of right mandible with m1-2; F/16; 03. MARSUL 701-51; fragment of right mandible with $\mathrm{m} 1-2 ; \mathrm{F} / 16 ; 05$. MARSUL 702-50; fragment of right mandible with dp4-m1; F/16; 06. MARSUL 707-51; fragment of right mandible with $\mathrm{m} 2-3 ; \mathrm{F} / 16 ; 11$. Locality and stratigraphic occurrence. The original material of this extinct species was collected in Lapa da Escrivania Nr. 5, Lagoa Santa, Minas Gerais (Late Pleistocene/Holocene). The new specimens come from both the Garivaldino and Sangão sites (Holocene).

Revised diagnosis. Upper diastema more rectilinear and more dorsally inclined than in Euryzygomatomys and Clyomys; premaxilla-maxilla suture, in ventral view, more anterior to the origin of the zygomatic arch than in Clyomys and Euryzygomatomys; lateral flange for the infraorbital nerve absent; condyloid and coronoid processes lower than in Clyomys; masseteric crest less developed than in Clyomys and Euryzygomatomys; cheek teeth with figure-eight occlusal surface; metafossette and mesofossettid very ephemeral.

Description. In the preserved rostra, the premaxilla-maxilla suture, in ventral view, is more anterior to the zygomatic arch than in Euryzygomatomys and Clyomys. The upper diastema is more straight and more dorsally inclined than in Euryzygomatomys and Clyomys. The premaxilla-maxilla suture divides the incisive foramina in two nearly equal portions; these foramina attenuate posteriorly more than in the new species of Clyomys described below, but less than in $E$. mordax. The maxillary fossa is well defined. The masseteric tuberosity is poorly developed. The alveolar sheath of the root of the upper incisor forms a protuberance lateral to the DP4; in certain specimens this protuberance is extended more anteromedially. The lateral flange for the infraorbital nerve is absent.

The mandible of Dicolpomys is similar to that of Clyomys, but more graceful. The masseteric fossa is deep. The masseteric crest is poorly developed when compared to Clyomys and Euryzygomatomys. The protuberance formed by the alveolus for the root of the lower incisor is well developed. The mandibular foramen is located proximal to the condyle. 
A

A $\quad B$

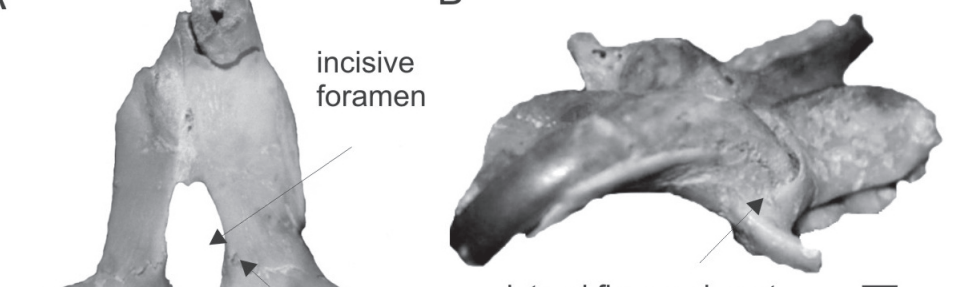

C

lateral flange absent

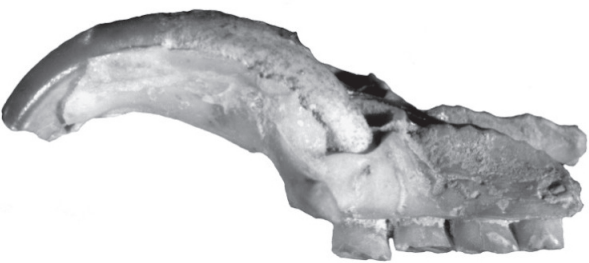

E reduced $\mathrm{M} 3$

metafossettte less persistent

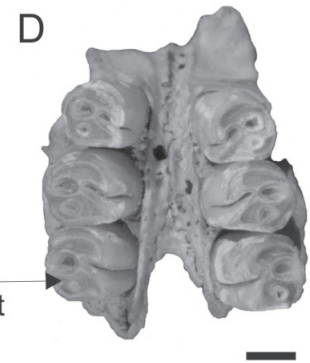

G
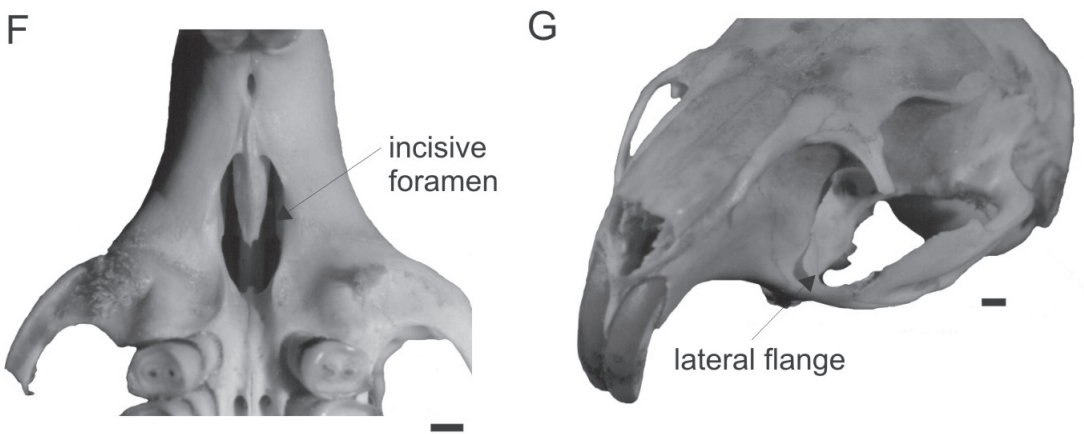

$\mathrm{H}$

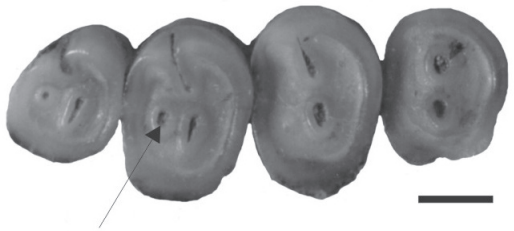

metafossettte more persistent
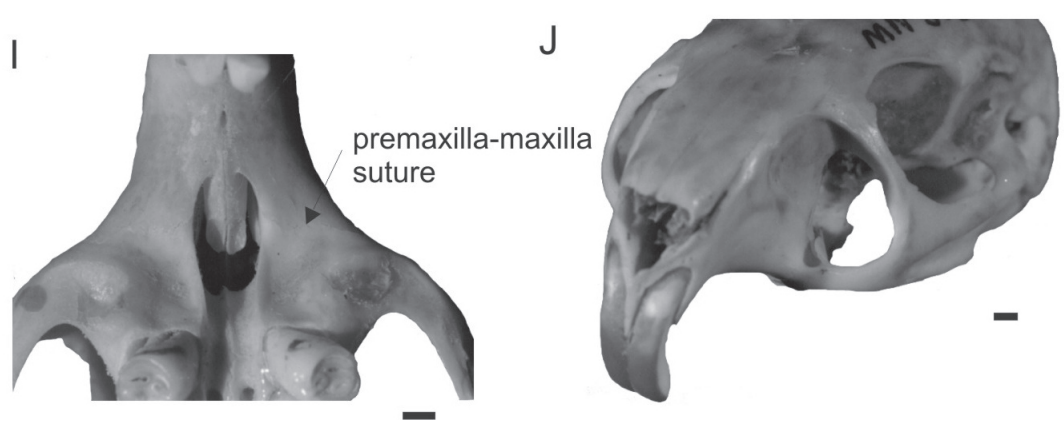

$\mathrm{K}$

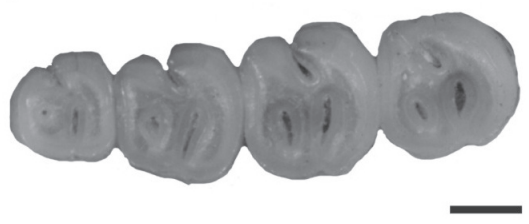

Figure 7. Clyomys species. A-E, C. riograndensis sp. nov., A-C, UNISC 1768-7, holotype, fragment of skull with both DP4-M3 in ventral (A), anterolateral (B), and lateral (C) views; D, UNISC 1702-11, palatal fragment with both DP4-M2 in occlusal view; E, UNISC 1700-6, left DP4-M3 in occlusal view; F-H, C. bishopi, MN 43074; F, anterior portion of the skull in ventral view; G, skull in anterolateral view, H, left DP4M3 in occlusal view; I-K, C. laticeps, I, MN 31549, anterior portion of the skull in ventral view; J, MN 31547, skull in anterolateral view; K MN 31549, left DP4-M3 in occlusal view. Scale bars $=1 \mathrm{~mm}$.

The cheek teeth have an eight-like occlusal figure, with single persistent lingual and labial flexus/ids that define two lobes (Figure 6). Both lobes of DP4-M3, and m1-3 are generally sub-equal. The hypoflexus is a little more reentrant than in the new species of Clyomys described below, but less than in E. mordax. The hypoflexus is opposite to the anterior flexus (or fossette), and its labial end is anteriorly oriented, especially in M1-2. Likewise, the anterior flexus is transverse or slightly anteriorly oriented (Figure 6B). The metafossette disappears very early ontogenetically, but a small vestige of this fossette can be observed in the DP4 and M1 of the juvenile UNISC 1763-14 (Figure 6E). The dp4 of juveniles has two lingual flexids and three lophids, but with increasing wear the anterior flexid closes forming an anterior fossettid. In older specimens, all flexids may become fossettids. The $\mathrm{m} 1$ shows a vestige of the mesofossettid in some juveniles (Figure 6J; UNISC 1562-2, 1765-18, MARSUL 671-54, 702-50). The shape of the lobes of m1-2 is variable; can be equal in size (Figure 6F), or the anterior lobe can be smaller and thinner (usually in $\mathrm{m} 1$ ), or even the posterior lobe can be smaller and wider (usually in $\mathrm{m} 2$, Figure 6I; Table 2). The $\mathrm{m} 3$ is clearly smaller than $\mathrm{m} 1-2$, and especially its posterior lobe is very reduced. In some individuals (UNISC 1696-2, 1697-4, 1702-7) the $\mathrm{m} 3$ has no distinct lobes (Figure 6I). 
Comments. Dicolpomys fossor shows a very simplified dental morphology, convergent to that of the Octodontidae, which led Winge (1888) to relate this species to extant members of that family. Later, Ameghino (1889) established the affinities of Dicolpomys with the Echimyidae (= Echinomyidae) by the presence of well defined and individualized roots. Dicolpomys fossor presents upper and lower molars with three roots like in Eumysopinae (Figure 6A, I; Emmons, 2005). Besides the mesoflexid closes earlier than the metaflexid like in the remaining Echimyidae (Verzi et al., 1994). Vucetich \& Verzi (1996) proposed that Dicolpomys is related to the Late Miocene echimyid Reigechimys from central Argentina.

Dicolpomys fossor would have had fossorial habits, as suggested especially by the morphology and deep implantation of the incisors (see Winge, 1888:pl. 8, fig.10; Winge, 1941; Verzi \& Olivares, 2006).

This is the first record of $D$. fossor for the Holocene of Rio Grande do Sul State.

\section{Clyomys Thomas, 1916}

Clyomys riograndensis sp. nov.

(Figures 7A-E, 8A-C; Tables 1,2)

Holotype. UNISC 1768-7, skull fragment with both DP4-M3. Hypodigm. UNISC 1511-1; fragment of right maxilla with M1?; A/6; 07. UNISC 1516-1; fragment of left maxilla with DP4-M1; A/ 6; 12. UNISC 1690-4; fragment of left maxilla with DP4-M1; C/6; 03. UNISC 1692-3; fragment of right maxilla with DP4-M3; C/6; 05. UNISC 1693-2; fragment of right mandible with dp4-m3; C/6;
06. UNISC 1694-3; fragment of left maxilla with $\mathrm{M} 1$; $\mathrm{C} / 6$; 07. UNISC 1696-1; fragment of left mandible with m1-3; C/6; 09. UNISC 1697-8; fragment of left maxilla with DP4-M1; C/6; 10. UNISC 1698-10; fragment of right maxilla with DP4-M2; C/6; 11. UNISC 1698-13; fragment of left maxilla with DP4-M1; C/6; 11. UNISC 1699-5; fragment of left mandible with dp4-m1; C/6; 12. UNISC 1699-7; fragment of left maxilla with DP4; C/6; 12. UNISC 1700-1; fragment of right mandible with dp4-m3; C/6; 13. UNISC 1700-2; fragment of left mandible with $\mathrm{dp} 4-\mathrm{m} 2 ; \mathrm{C} / 6$; 13 . UNISC 1700-6; fragment of left maxilla with DP4-M3; C/6; 13. UNISC 1700-7; fragment of right maxilla with DP4-M2; C/6; 13. UNISC 1701-1; fragment of right mandible with $\mathrm{m} 3$; C/6; 14. UNISC 17012 ; fragment of right mandible with dp4-m1; C/6; 14. UNISC 17021 ; fragment of right mandible with dp4-m1; C/6; 15. UNISC 17026; fragment of right mandible with $\mathrm{m} 1 ; \mathrm{C} / 6 ; 15$. UNISC 1702-10; palatal fragment with left M1-2 and right DP4-M1; C/6; 15. UNISC 1702-11; palatal fragment with both DP4-M2; C/6; 15. UNISC 1703-1; fragment of right mandible with dp4-m1; C/6; 16. UNISC 1703-3; fragment of left mandible with dp4-m2; C/6; 16. UNISC 1703-4; fragment of left mandible with dp4-m2; C/6; 16. UNISC 1703-7; fragment of left mandible with dp4; C/6; 16. UNISC 17046; fragment of left mandible with dp4-m1; C/6; 17. UNISC 1704-8; fragment of right mandible with $\mathrm{m} 2 ; \mathrm{C} / 6 ; 17$. UNISC 1706-1; fragment of left mandible with dp4-m1; C/6; 17. UNISC 1706-5; fragment of right maxilla with DP4; C/6; 19. UNISC 1717-1; fragment of right maxilla with $\mathrm{M} 1 ; \mathrm{C} / 6 ; 19$. UNISC 1729-1; fragment of right mandible with dp4-m2; C/6; 19. UNISC 1756-21; fragment of right mandible with $\mathrm{m} 1$; D/6; 06. UNISC 1757-4; fragment of left maxilla with DP4-M1; D/6; 07. UNISC 1757- 8; fragment of right maxilla with DP4-M1; D/6; 07. UNISC 1758-3; fragment of right maxilla with M1; D/6; 08. UNISC 1758-6; fragment of right maxilla with
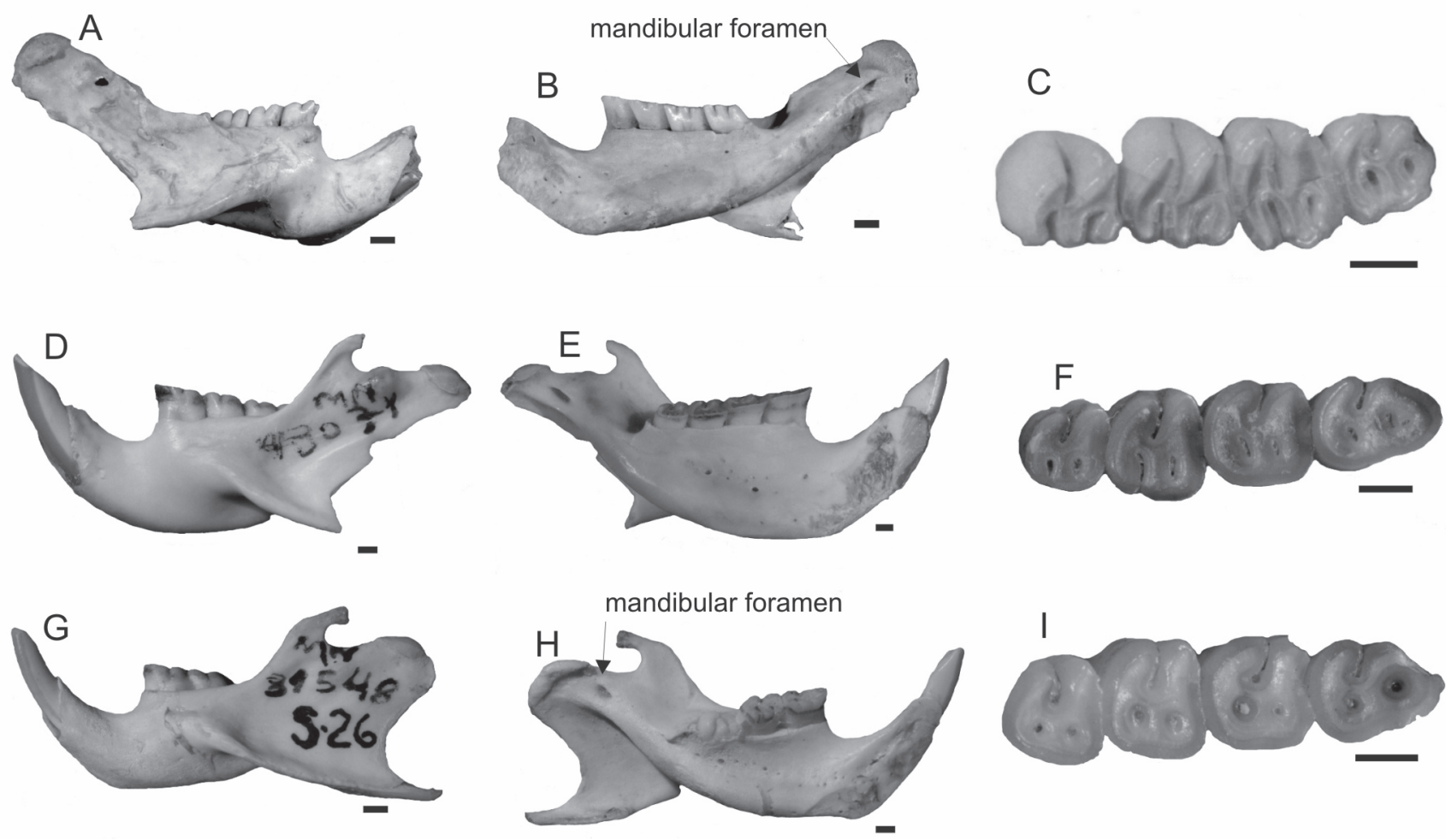

Figure 8. Clyomys species. A-C, C. riograndensis sp. nov., UNISC 1700-1, fragment of right mandible with dp4-m3 in lateral A, and medial (B) views; C, right dp4-m3 represented as left in occlusal view; D-F, C. bishopi, MN 43071, left mandible in lateral (D) and medial (E) views; F, dp4-m3 in occlusal view; G-I, C. laticeps, G-H, MN 31548, left mandible in lateral (G), and medial (H) views; I, MN 31547, left dp4-m3 in occlusal view. Scale bars $=1 \mathrm{~mm}$. 
DP4-M2; D/6; 08. UNISC 1758-8; fragment of left mandible with dp4; D/6; 08. UNISC 1759-7; fragment of left mandible with m1-2; $\mathrm{D} / 6$; 09. UNISC 1760-2; fragment of right maxilla with $\mathrm{M} 1 ; \mathrm{D} / 6$; 10. UNISC 1761-6; fragment of left maxilla with M2; D/6; 11 . UNISC 1762-1; fragment of right maxilla with DP4; D/6; 12. UNISC 1762-3; fragment of right maxilla with DP4-M1; D/6; 12. UNISC 1763-3; fragment of left maxilla with M1; D/6; 13. UNISC 1763-5; fragment of right maxilla with DP4; D/6; 13. UNISC 1763-8; fragment of left maxilla with DP4; D/6; 13. UNISC 1763-9; fragment of right maxilla with DP4; D/6; 13. UNISC 1763-10; fragment of left maxilla with DP4-M1; D/6; 13. UNISC 1763-18; fragment of left mandible with dp4; D/6; 13. UNISC 1763-23; fragment of right mandible with dp4-m3; D/6; 13. UNISC 1764-4; fragment of right mandible with dp4-m2; D/6; 14. UNISC 1765-3; fragment of left maxilla with M1; D/6; 15. UNISC 1765-6; fragment of left maxilla with $\mathrm{M} 1 ; \mathrm{D} / 6$; 15. UNISC 1765-7; fragment of right maxilla with M1; $\mathrm{D} / 6$; 15. UNISC 1765-8; fragment of right maxilla with DP4-M1; D/6; 15. UNISC 1765-9; fragment of right maxilla with DP4-M1; $\mathrm{D} / 6$; 15. UNISC 1765-10; fragment of left mandible with dp4-m3; $\mathrm{D} / 6$; 15. UNISC 1765-15; fragment of right mandible with $\mathrm{m} 1$; D/ 6; 15. UNISC 1765-16; fragment of right mandible with dp4-m1; $\mathrm{D} / 6$; 15. UNISC 1766-6; fragment of left mandible with $\mathrm{m} 1$; D/6; 16. UNISC 1767-1; fragment of left maxilla with M1; D/6; 17. UNISC 1767-2; fragment of left maxilla with M1?; D/6; 17. UNISC 1767-4; fragment of left maxilla with DP4-M1; D/6; 17. UNISC 1767-10; fragment of right mandible with $\mathrm{m} 1-3$; D/6; 17. UNISC 1768-1; fragment of right maxilla with M1-2; D/6; 18. UNISC 1768-7 (holotype); fragment of skull with both DP4-M3; D/6; 18. UNISC 1768-9; fragment of right mandible with m1-3; D/6; 18. UNISC 1768-11; fragment of left mandible with $\mathrm{m} 1 ; \mathrm{D} / 6 ; 18$. UNISC 1769-2; fragment of left mandible with m1-2; D/6; 19. UNISC 1769-3; fragment of right mandible with dp4-m2; D/6; 19. UNISC 1769-8; fragment of right mandible with dp4-m2; D/6; 19. UNISC 1769-11; fragment of left mandible with $\mathrm{m} 1 ; \mathrm{D} / 6 ; 19$. UNISC 1769-16; fragment of right maxilla with DP4-M2; D/6; 19. UNISC 1769-19; fragment of left maxilla with DP4-M1; D/6; 19. UNISC 1770-6; fragment of right maxilla with DP4-M2; D/6; 20. UNISC 1770-8; fragment of right maxilla with M1?; D/6; 20. MARSUL 667-38; fragment of right mandible with dp4-m2; E/12; 12. MARSUL 683-14; fragment of left maxilla with DP4-M1; F/8; 02. MARSUL 705-50; fragment of left mandible with dp4-m1; F/16; 09.

Etymology. riograndensis in reference to Rio Grande do Sul State, where it was collected.

Locality and stratigraphic occurrence. The holotype comes from the Garivaldino site. It was collected by P. Mentz-Ribeiro during the Project of the Archaeological Survey in the Valleys of the Taquari and Cai rivers (Mentz-Ribeiro et al., 1989). The species is known from the type locality and the Sangão site (Holocene). For details of the provenance of the rest of material see hypodigm.

Diagnosis. It differs from the two living species, Clyomys laticeps (Thomas) and C. bishopi Ávila-Pires \& Wutke, in: shorter diastema; narrower and more elliptical incisive foramina; premaxilla limiting more than half the incisive foramina length; protuberance of the bottom of the upper incisor lateral to DP4; lesser development of the masseteric tuberosity; absence of the lateral flange for the infraorbital nerve; mandibular foramen more proximal to the condyle; greater reduction of $\mathrm{M} 3$; and lesser persistence of the metafossette, especially in M2 and M3.

Description. This is the smallest species of Clyomys (see Table 2); although there is a partial overlap of the measurements of $C$. riograndensis sp.nov. and $C$. laticeps from Brasília and Xavantina (see Ávila-Pires \& Wutke, 1981), all specimens of the former are smaller than the largest specimens of the latter. The upper diastema is proportionally a little shorter than in $C$. laticeps $(\chi=10.47 \mathrm{~mm} ; \mathrm{SD}=0.26$ $\mathrm{mm})$ and $C$. bishopi $(\chi=11.0 \mathrm{~mm} ; \mathrm{SD}=0.33 \mathrm{~mm})$. The incisive foramina are narrower and they are more elliptical than in $C$. laticeps and $C$. bishopi. The premaxilla limits more than half of the incisive foramina length. The masseteric tuberosity is less developed than in the other species; it begins more proximal to the DP4 than in Euryzygomatomys. Different to the living species of Clyomys, the protuberance of the bottom of the upper incisor is not antero-lateral to the DP4 but lateral to this tooth, and in some specimens less prominent. The lateral flange for the infraorbital nerve is absent, different from the extant species of the genus. The mandible is slightly less robust than that in $C$. laticeps and $C$. bishopi. The lower diastema has a step anterior to the dp4 much more marked than in the extant species, similar to that of the fossil specimen MLP 91-IV-25-135 (Clyomys sp.) from Argentina (Vucetich et $a l ., 1997)$; the anterior portion of the diastema is more steep than in MLP 91-IV-25-135. The masseteric fossa is less defined than in the extant species, but the difference is very tenuous and a little variable in the fossil sample. The masseteric crest begins at the level of the anterior portion of the $\mathrm{m} 1$, as occurs in the extant species, but more anterior than in MLP 91-IV-25135. The protuberance formed by the bottom of the alveolus for the lower incisor is displaced in the direction of the condyle. The mandibular foramen is more ventral and posterior than in the living species.

The upper molars have less reentrant flexi than in Euryzygomatomys. The hypoflexus is a little deeper than in MLP 91-IV-25-135, at least in M1, and it is less turned anteriorly than in the other species of the genus. The anterior fossette persists longer than the metafossette; the latter is less persistent than in the other species of Clyomys, especially in M2 and M3. M3 is proportionally smaller than in the extant species. The lower molars also show less reentrant flexids than in Euryzygomatomys. Nevertheless, the flexids are more reentrant than those of the recent Clyomys, especially the hypoflexid, although this is a variable feature. The hypoflexid is not so turned posteriorly as in the fossil from Argentina (MLP 91-IV-25-135, 91-IV-25-116), although this character showed some variabillity in the material studied. The mesoflexid closes a little before the metaflexid. The $\mathrm{m} 1$ and $\mathrm{m} 2$ are sub-equal in size, not showing the difference seen in MLP 91-IV-25-135, in which $\mathrm{m} 2$ is larger than $\mathrm{m} 1$. The $\mathrm{m} 3$ is more reduced than in MLP 91-IV-25-135.

Comments. Thomas (1909) described the species Echimys laticeps (=Clyomys laticeps), and reported its differences from Echimys spinosus (=Euryzygomatomys spinosus) based on recent material from the region of Lagoa Santa, Minas Gerais. In 1916, Thomas established the genus Clyomys to encompass the species $C$. laticeps (=Echimys laticeps), and he characterized this genus through its large foreclaws, hypertrophied auditive bullae and small molars with posterior transverse cleft [metaflexus] of the last upper molar less 
persistent than in Euryzygomatomys. Ávila-Pires \& Wutke (1981) described C. bishopi, based on material from São Paulo, and differentiated it from the type species through external characteristics, mainly the color of the fur. Bezerra (2003) did not identify substantial differences between the two species, and suggested that they represent a single taxon.

The material here studied is referred to Clyomys on the basis of molar morphology, with little reentrant flexi/flexids and ephemeral metafossette (Thomas, 1916; Verzi et al., 1995).

Clyomys laticeps currently occurs in the Brazilian Cerrado and Paraguayan Chaco, and C. bishopi in islands of Cerrado in the State of São Paulo (Bezerra, 2003). These species inhabit open areas and show fossorial habits. The deeper insertion of the lower incisors -as indicated by the position of the mandibular foramen-, suggests that $C$. riograndensis sp.nov. would have used the incisors for digging more than the extant species (see Winge, 1888; Verzi \& Olivares, 2006).

Vucetich et al. (1997) described Pleistocene specimens of Clyomys for central-eastern Argentina, which represent a different species from those distributed in Paraguay and Brazil. Another specimen tentatively referred to this genus was described for the Late Miocene of Argentina central (Montalvo et al., 1998). For the Quaternary of Brazil, Clyomys was recorded for the State of Mato Grosso do Sul, in the Serra da Bodoquena (Salles et al., 2006), and C. laticeps for the State of Minas Gerais, in Lagoa Santa (Lund, 1839b). The material here studied is the first record of the genus for the Holocene of Rio Grande do Sul.

\section{Family MYOCASTORIDAE Ameghino, 1902 Myocastor coypus (Molina, 1782)}

Material. MARSUL 669-52, right M3 isolated; MARSUL 70415 , anterior fragment of right mandible with $\mathrm{m} 1$.

Comments. Currently M. coypus is the only living species of the genus and occurs in Paraguay, Uruguay, Bolivia, Argentina, Chile, and Southern Brazil (Eisenberg \& Redford, 1989).

During the Quaternary M. coypus had a much wider distribution in Brazil, extending at least up to Bahia (Cartelle \& Lessa, 1989). The material here assigned to this species is very scarce (see Table 1).

\section{DISCUSSION}

The assemblages described in this paper are among the best caviomorph samples known for the Quaternary of Brazil. These include a new species of Clyomys, and the first record of Phyllomys sp., Euryzygomatomys mordax and Dicolpomys fossor for southern Brazil, allowing to enlarge the knowledge of the temporal and geographic distribution of these species. In addition, the great abundance of materials, including the first mandibles of E. mordax and maxillae of $D$. fossor, supports the taxonomic status of these genera and species and allows future morphological variability studies.

Previous records of caviomorphs for the Holocene and the Pleistocene of Rio Grande do Sul are scarce. For the Holocene, Agouti paca, Dasyprocta azarae, Myocastor coypus, Hydrochoerus hydrochaeris, Cavia sp., C. aperea, C. magna, Ctenomys sp., and Echimys sp. (e.g., Mentz-Ribeiro et al., 1989; Rosa, 1996, 2006a, b; Dias, 2003; Queiroz, 2004; Schmitz et al., 1997) were recorded, but some of these materials are in need of a taxonomic revision. Pleistocene caviomorphs include $H$. hydrochaeris, M. coypus, Microcavia sp., Dolichotinae indet., and Echimyidae indet. (Bombin, 1976; Oliveira, 1992; Oliveira \& Lavina, 2000; Rodrigues \& Ferigolo, 2004; Ubilla et al., 2007). In addition, Buchmann (1994, 2002) listed Ctenomys sp. and Cavia sp. for Concheiros locality, Santa Vitoria do Palmar Municipality. However, a revision of the material analyzed by Buchmann ( $\mathrm{PH}$, pers. obs.) rejects these identifications. Presence of families Hydrochoeridae, Caviidae, Echimyidae, Myocastoridae, and the species $M$. coypus and H. hydrochaeris (Rodrigues \& Ferigolo, 2004) is confident at least since the Late Pleistocene. These occur at present in Rio Grande do Sul, with a very ample distribution.

In the rest of Brazil, caviomorphs are widely recorded, but these records are punctual and fragmentary except for the faunas from São Paulo and Minas Gerais. The seminal works of Lund (1839a,b; 1840a,b) and Winge (1888) report the most important Quaternary caviomorph assemblages of Brazil, comprising about 22 taxa from the region of Lagoa Santa, Minas Gerais.

The Holocene caviomorph fauna from Rio Grande do Sul, mainly the Echimyidae, shows taxonomic similarities with the Quaternary caviomorph faunas from central Brazil (see e.g., Winge, 1888; Ameghino, 1907; Paula-Couto, 1946). In addition, this fauna presents also "pampean" taxa, like Ctenomys, recorded in the Pleistocene of Argentina, Uruguay, Bolivia, and Chile (Mones \& Castiglioni, 1979; Marshall et al., 1984; Reig et al., 1990), and Cavia magna (Ximenez, 1980). The similarity between the Quaternary mastofauna from southern Brazil and that from Argentina and Uruguay, which has already been suggested (e.g., Bombin, 1975; Cartelle, 1999), became established for the Late Pleistocene through the megafauna and caviomorph rodents like Microcavia and Dolichotinae (Tonni, 1981; Ubilla et al., 1999). Consequently, the Rio Grande do Sul fauna was a mixture of "pampean" and brazilian taxa; it is possible that one or other faunal elements were predominant in the composition of the fauna at different times. Nowadays, both influences are evident, and two biogeographic neotropical subregions are represented: Chaco and Parana (Morrone, 2001).

The record of C. magna only in Sangão site agrees with its current geographic distribution (see Ximenez, 1980). It is possible that this taxon has kept such a distribution pattern since the Holocene, extending to the North through the littoral of Rio Grande do Sul State, but not occurring in interior localities like Garivaldino site. C. aperea is recorded in both sites, although its record is very scarce. Despite this poor record in our sample, $C$. aperea is one of the best represented taxa in other archaeological sites of Rio Grande do Sul, being recorded in central, littoral and southern portion of the state (e.g., Schmitz et al., 1997; Rosa 2006a; Silva \& Rosa, 2006).

For the Holocene of Rio Grande do Sul, Ctenomys is recorded mainly in sites from the Coastal Plain (e.g., Silva \& 
Rosa, 2006). The previous record in Garivaldino site (MentzRibeiro et al., 1989) was not confirmed (see above).

The records of Phyllomys sp. and Dicolpomys fossor in Rio Grande do Sul extend their distribution southward, and chronologically to the Late Holocene, because they were known, until now, only from the Late Pleistocene/Early Holocene in central Brazil (Minas Gerais and São Paulo; Lund, 1839a,b, 1840a,b; Winge, 1888; Ameghino, 1907; Souza-Cunha \& Guimarães, 1978; Castro \& Langer, 2005). Phyllomys shows since the Quaternary the ample geographic distribution that presents nowadays, being recorded in central and southern Brazil. Euryzygomatomys mordax has also its geographic occurrence extended southward.

Clyomys riograndensis sp.nov. extends the distribution of the genus to the south in the Holocene (at least until 3,700 years BP). The earliest records of Clyomys also show a different geographic distribution than the current one, being distributed in the Early Pleistocene (Ensenadan SALMA) of Argentina (Vucetich et al., 1997). Today, Clyomys occurs only in the Brazilian Cerrado, and Paraguayan Chaco (Woods \& Kilpatrick, 2005).

The new records support the statement of Vucetich \& Verzi (2002) that very recent extinctions of caviomorphs occurred in northern South America. The Holocene brazilian caviomorph fauna is more diverse than today, since a genus and at least three species became extinct. Euryzygomatomys mordax became extinct after 7,200 years BP, and Clyomys riograndensis sp.nov. and $D$. fossor after 3,700 years BP (see Table 1). Vucetich \& Verzi (1999) had suggested that caviomorph faunas from central Brazil (Cerrado) and central Argentina had different evolutionary characteristics in the Pleistocene, that from Argentina being more stable. Also, in this aspect, the Holocene caviomorph fauna from Rio Grande do Sul was like that from central Brazil, presenting extinctions of genera and species.

The caviomorphs record from Garivaldino and Sangão sites is essentially homogeneous (Table 1), with only scarce breaks in the pattern. This probably reflects an absence of climatic pulses that could have interfered with the distribution of the species. That is, the climate was probably relatively constant, with mild and gradual changes, as can also be interpreted from the stratigraphic distribution of the marsupials in these sites (Hadler et al., in press).

There are differences in faunal composition between the analyzed sites: C. magna, Ctenomys sp. and $M$. coypus are taxa exclusive of the Sangão site, whereas E. mordax is only found at Garivaldino. This could be due to local environmental differences, Sangão being an area more humid, with the Sinos River course just below the rock shelter, permitting the presence of the semi-aquatic M. coypus and C. magna. Causes for the distinctive distribution of E. mordax and Ctenomys sp. are not evident.

The occurrence of fossorial taxa of open areas, E. mordax, C. riograndensis sp.nov., D. fossor and Ctenomys, at the same levels as that of Phyllomys, typical of forested areas, may indicate a mosaic environment with grasslands and gallery forests. Furthermore, the high abundance of

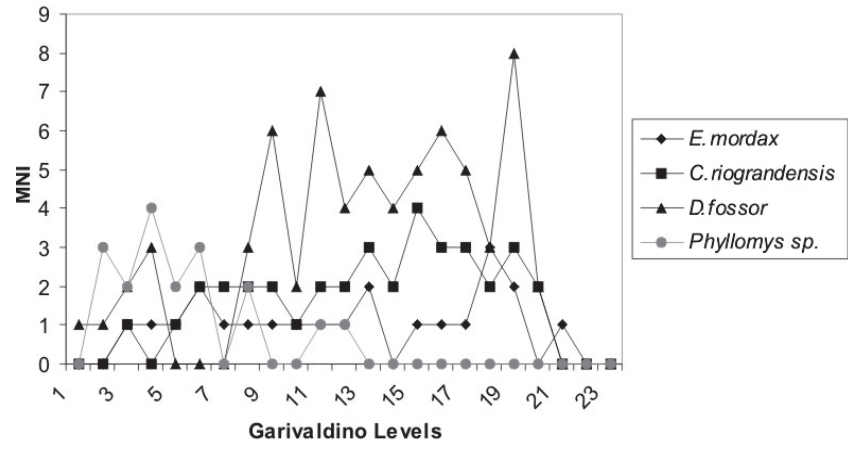

Figure 9. Minimal number of individuals (MNI) of the Echimyidae species in Garivaldino site.

caviomorphs presumably related to grasslands attests to the predominance of these environments (Figure 9). These evidences are comparable with those provided by marsupials for the same areas (Hadler et al., in press) and agree with palynological data. These latter have shown a scenario of grasslands predominating during the Late Pleistocene ( \pm 40,000 years BP), substituted by forests, which were fully established by the end of Holocene. During the Early and Middle Holocene, climate became warmer, but still dry, grasslands continuing to predominate. General replacement of grasslands by forests occurred around 1,000 years BP, determined by a very humid climate, with no drought seasons (Behling et al., 2001; Grala \& Lorscheitter, 2001; Behling, 2002; Bauermann, 2003; Behling et al., 2004, 2005).

Still according to palynological data, forest expansion would have started at different moments in some areas of Rio Grande do Sul. Whereas in the region of Serra Velha (Montenegro County, near Garivaldino site) forest expansion started at about 6,000 years BP, in Barrocadas locality (Santo Antônio da Patrulha County, near Sangão site) it occurred around 3,000 years BP(Grala \& Lorscheitter, 2001; Bauermann, 2003). This is not consistent with the presence of Phyllomys sp. in both sites around 8,000 years BP (Table 1), indicating already in this moment the presence of some forest. A possible explanation is that this rodent might have inhabited gallery forests. In this context, the proximity of Sangão site to Sinos River would have allowed the presence of Phyllomys at Early Holocene, even though the expansion of forests seem to have occurred only at 3,000 years BP in Santo Antônio da Patrulha (Bauermann, 2003).

\section{ACKNOWLEDGMENTS}

The authors thank M. Jardim (MCN/FZBRS), J. A. de Oliveira (MN), M. de Vivo (MZUSP) and K. Aaris-Sørensen (ZMUC) for accessing to the collections under their care; S. Klamt (UNISC) and A. Jacobus (MARSUL) for material loaning; A. Dias for the archaeological data; R. Lopes for the map; L. F. Lopes for the photography job; and A. Leyva for the English translation. Finantial support was granted by $\mathrm{CNPq}$ (PH, studentship award) and FAPERGS (AMR, PROAPP 0413804). Suggestions from L. Flynn and an anonymous reviewer gratly improved the manuscript. 


\section{REFERENCES}

Ameghino, F. 1889. Contribución al conocimiento de los mamíferos fósiles de la República Argentina. Actas de la Academia de Ciencias de Córdoba, 6:1-1027.

Ameghino, F. 1907. Notas sobre una pequeña colección de huesos de mamíferos procedentes de las grutas calcáreas de Iporanga en el estado de São Paulo - Brazil. Revista do Museu Paulista, 7:59-124.

Ávila-Pires, F.D. de \& Wutke, M.R.C. 1981. Taxonomia e evolução de Clyomys Thomas, 1916 (Rodentia, Echimyidae). Revista Brasileira de Biologia, 41(3):529-534.

Auler, A.S; Piló, L.B.; Smart, P.L.; Wang, X.; Hoffmann, D.; Richards, D.A.; Edwards, R.L.; Neves, W.A. \& Cheng, H. 2006. U-series dating and taphonomy of Quaternary vertebrates from Brazilian caves. Palaeogeography, Palaeoclimatology, Palaeoecology, 240:508-522.

Barros-Barreto, C.N.G.; De Blasiis, P.A.D.; Dias-Neto, C.M.; Karmann, I.; Lino, C.F. \& Robrahn, E.M. 1982. Abismo Ponta de Flecha: um projeto arqueológico, paleontológico e geológico no médio Ribeira de Iguape, São Paulo. Revista Pré-História, 3(4):195-215.

Bauermann, S.G. 2003. Análises Palinológicas e Evolução Paleovegetacional e Paleoambiental das Turfeiras de Barrocadas e Águas Claras, Planície Costeira do Rio Grande do Sul, Brasil. Programa de Pós-Graduação em Geociências, Universidade Federal do Rio Grande do Sul, Tese de Doutorado, $137 \mathrm{p}$.

Behling, H. 2002. South and Southeast Brazilian grasslands during Late Quaternary times: a synthesis. Palaeogeography, Palaeoclimatology, Palaeoecology, 177:19-27.

Behling, H.; Bauermann, S.G. \& Neves, P.C. 2001. Holocene environmental changes from the São Francisco de Paula region, southern Brazil. Journal of South American Earth Sciences, 14:631-639.

Behling, H.; Pillar, V.; Orlóci, L. \& Bauermann, S.G. 2004. Late Quaternary Araucaria forest, grassland (Campos), fire and climate dynamics, studied by high resolution pollen, charcoal and multivariate analysis of the Cambara do Sul core in southern Brazil. Palaeogeography, Palaeoclimatology, Palaeoecology, 203:277-297.

Behling, H.; Pillar, V.; Orlóci, L. \& Bauermann, S.G. 2005. Late Quaternary grassland (Campos), gallery forest, fire and climate dynamics, studied by pollen, charcoal and multivariate analysis of the São Francisco de Assis core in western Rio Grande do Sul (southern Brazil). Review of Palaeobotany and Palynology, 133:235-248.

Bezerra, A.M.R. 2003. Variabilidade morfológica e status taxonômico das amostras populacionais do gênero Clyomys (Rodentia: Echimyidae). Mastozoologia Neotropical, 10(1):185186.

Bombin, M. 1975. Afinidade paleoecológica, cronológica e estratigráfica do componente de megamamíferos na biota do Quaternário terminal da Província de Buenos Aires (Argentina), Uruguai e Rio Grande do Sul (Brasil). Comunicações do Museu de Ciências da PUCRS, Zoologia, 9:1-28.

Bombin, M. 1976. Modelo paleoecológico evolutivo para o neoquaternário da região da campanha-oeste do Rio Grande do Sul (Brasil). A Formação Touro Passo, seu conteúdo fossilífero e a pedogênese pós-deposicional. Comunicações do Museu de Ciências da PUCRS, Zoologia, 15:1-90.

Buchmann, F.S.C. 1994. Estudo macrofossilifero na porção sul da
Planície Costeira do Rio Grande do Sul, Brasil. Curso de Graduação em Oceanografia, Universidade Federal de Rio Grande, Monografia de Conclusão, 78 p.

Buchmann, F.S.C. 2002. Bioclastos de organismos terrestres e marinhos na praia e plataforma interna do Rio Grande do Sul: natureza, distribuição, origem e significado geológico. Programa de Pós-Graduação em Geociências, Universidade Federal do Rio Grande do Sul, Tese de Doutorado, 108 p.

Busch, C.; Antinuchi, C.D.; del Valle, J.C.; Kittlein, M.J.; Malizia, A.I.; Vassallo, A.I.; Zenuto, R.R. 2000. Population ecology of subterranean rodents. In: A.E. Lacey; J.L. Patton \& G.N. Cameron (eds.) Life underground. The biology of subterranean rodents, University of Chicago Press, p. 183-226.

Cartelle, C. 1999. Pleistocene Mammals of the Cerrado and Caatinga of Brazil. In J.F. Eisenberg \& K.H. Redford (eds.) Mammals of the Neotropics, the Central Neotropics, The University of Chicago Press, p. 27-46.

Cartelle, C. \& Lessa, G. 1989. Presença de Myocastor coypus (Molina, 1782), Rodentia, Myocastoridae, do Pleistoceno final-Holoceno, no centro-oeste da Bahia. In: CONGRESSO BRASILEIRO DE PALEONTOLOGIA, 11, 1989. Anais, Curitiba, SBP, p. 583-591.

Castro, M.C. \& Langer, M.C. 2005. Inventário preliminar da fauna de mamíferos Quaternários do Abismo Iguatemi, Vale do Ribeira, SP. In: CONGRESSO BRASILEIRO DE PALEONTOlOGIA, 19, 2005. Anais, Aracaju, SBP. (CDROM).

Cherem, J.J. 1999. Descrição do sincrânio e dentição de Cavia aperea Erxleben, 1777 (Rodentia, Caviidae) e comparação com as demais espécies do gênero do sul-sudeste do Brasil. Programa de Pós-Graduação em Biociências, Pontifícia Universidade Católica do Rio Grande do Sul, Dissertação de Mestrado, 107 p.

Cherem, J.J; Olimpio, J. \& Ximenez, A. 1999. Descrição de uma nova espécie do gênero Cavia Pallas, 1766 (Mammalia Caviidae) das Ilhas dos Moleques do Sul, Santa Catarina, Sul do Brasil. Biotemas, 12(1):95-117.

Contreras, J.R. 1964. Datos acerca de la variación intrapoblacional de la morfología de los molares de entidades de los géneros Galea y Microcavia (Rodentia, Caviidae). Ameghiniana, 3(8):235-255.

Dias, A.S. 2003. Sistemas de Assentamento e Estilo Tecnológico: uma proposta interpretativa para a Ocupação Pré-colonial do Alto Vale do Rio dos Sinos, Rio Grande do Sul. Programa de Pós-Graduação em Arqueologia, Universidade de São Paulo, Tese de Doutorado, $326 \mathrm{p}$.

Dias, A.S. 2004. Diversificar para poblar: el contexto arqueológico brasileño en la transición Pleistoceno-Holoceno. Complutum, 15:249-263.

Dias, A.S. \& Jacobus, A.L. 2003. Quão antigo é o povoamento do Sul do Brasil? Revista do CEPA, 27(38):39-67.

Eisenberg, J.F. \& Redford, K.H. 1989. Mammals of the Neotropics, the Central Neotropics. $1^{\text {a }}$ ed. Chicago, The University of Chicago Press, $609 \mathrm{p}$.

Emmons, L.H. 2005. A revision of the genera of arboreal Echimyidae (Rodentia: Echimyidae, Echimyinae), with descriptions of two new genera. In: E.A. Lacey \& P. Myers (eds.) Mammalian Diversification: from Chromosomes to Phylogeography (a celebration of the Career of James L. Patton), University of California Publications, p. 247-310.

Emmons, L.H. \& Vucetich, M.G. 1998. The identity of Winge's Lasiuromys villosus and the description of a new genus of 
Echimyid Rodent (Rodentia: Echimyidae). American Museum Novitates, 3223:1-12.

Emmons, L.H.; Leite, Y.L.R.; Kock, D. \& Costa, L.P. 2002. A review of the named forms of Phyllomys (Rodentia: Echimyidae) with the description of a new species from coastal Brazil. American Museum Novitates, 3380:1-40.

Flynn, J.J.; Wyss, A.R.; Croft, D.A. \& Charrier, R. 2003. The Tinguiririca fauna, Chile: biochronology, paleoecology, biogeography, and a new earliest Oligocene South American Land Mammal 'Age'. Palaeogeography, Palaeoclimatology, Palaeoecology, 195:229-259.

Frailey, D.; Campbell, K.E. \& Wolff, R.G. 1980. Additions to the Knowledge of Hippocamelus, Ctenomys and Myocastor from the middle Pleistocene of the Tarija Basin, Bolivia. Occasional Papers of the Museum of Natural History, 85:1-14.

Freitas, T.R.O. de. 1995. Geographic distribution and conservation of four species of the genus Ctenomys in Southern Brazil. Studies on Neotropical Fauna and Environment, 30:53-59

Freitas, T.R.O de. 2006. Cytogenetics status of four Ctenomys species in the south of Brazil. Genetica, 126:227-235.

Galewski, T.; Mauffrey, J.F.; Leite, Y.L.R.; Patton, J.L. \& Douzery, E.J.P. 2005. Ecomorphological diversification among South American spiny rats (Rodentia; Echimyidae): a phylogenetic and chronological approach. Molecular Phylogenetics and Evolution, 34:601-615.

Gonçalves, G.L. 2007. Diferenciação genética e geográfica intraespecifica em Ctenomys Blainville, 1826 (Mammalia: Rodentia) nos campos sulinos. Programa de Pós-Graduação em Biologia Animal, Universidade Federal do Rio Grande do Sul, Dissertação de Mestrado, 75 p.

Grala, M.M.; Lorscheitter, M.L. 2001. The Holocene palaeoenvironment in the Serra Velha region, RS, Brazil, through a study of plant succession. Pesquisas em Geociências, 28(2):245-249.

Guérin, C. 1991. La faune de vertébrés du Pléistocène supérieur de l'aire archéologique de São Raimundo Nonato (Piauí, Brésil). Comptes Rendus de l'Academie des Sciences, Serie II Mecanique Physique Chimie Sciences de 1'Univers Sciences de la Terre, 312(2):567-572.

Hadler, P.; Goin, F.J.; Ferigolo, J.; Ribeiro, A.M. (in press). Environmental change and marsupial assemblages in Holocene successions of Southern Brazil. Mammalian Biology.

Hoffstetter, R. 1963. La faune pléistocène de Tarija (Bolivie): note préliminaire. Bulletin du Muséum National d'Histoire Naturelle, Serie 2, 35(2): 194-203.

Iack-Ximenes, G.E.; De Vivo, M. \& Percequillo, A.R. 2005. A new genus for Loncheres grandis Wagner, 1845, with taxonomic comments on other arboreal echimyids (Rodentia, Echimyidae). Arquivos do Museu Nacional, 63(1):89-112.

Kraglievich, L. 1930. Diagnosis osteológico-dentaria de los géneros vivientes de la subfamilia "Caviinae". Anales del Museo Nacional de Historia Natural "Bernardino Rivadavia”, 36:59-96.

Leite, Y.L.R. 2003. Evolution and systematics of the Atlantic Tree Rats, genus Phyllomys (Rodentia, Echimyidae), with description of two new species. Berkeley, University of California Press, $118 \mathrm{p}$.

Lessa, E.P. \& Cook, J.A. 1998. The molecular phylogenetics of tuco-tucos (genus Ctenomys, Rodentia: Octodontidae) suggests an early burst of speciation. Molecular Phylogenetics and Evolution, 9(1):88-99.

Lino, C.F.; Dias-Neto, C.M.; Trajano, E.; Gusso, G.L.N.; Karmann, I. \& Rodrigues, R. 1979. Paleontologia das Cavernas do Vale do
Ribeira - Exploração I- Abismo do Fóssil (SP-145). Resultados Parciais. In: SIMPÓSIO REGIONAL DE GEOLOGIA, 2, 1979. Atas, Rio Claro, SBG, p.257-268.

Lund, P.W.1839a. Coup d'oeil sur les espèces éteintes de mammifères du Brésil, extrait de quelques mémoires présentés à l'Académie Royale des Sciences de Copenhagen. Annales des Sciences Naturelles, Série 2, 11:214-234.

Lund, P.W. 1839b. Blik paa Brasiliens Dyreverden för Sidste Jordomvaeltning. Anden Afhandling: Pattedyrene. Det Kongelige Danske Videnskabernes Selskabs naturvidenskabelige og Mathematiske Afhandlinger, 8:61-144.

Lund, P.W. 1840a. Blik paa Brasiliens Dyreverden för Sidste Jordomvaeltning. Tredie Afhandling: Fortsaettelse af Pattedyrene. Det Kongelige Danske Videnskabernes Selskabs naturvidenskabelige og Mathematiske Afhandlinger, 8:217-272.

Lund, P.W. 1840b. Nouvelles recherches sur la faune fossile du Brésil (extraits d'une letter adressée aux rédacteurs, et datée de Lagoa Santa, ler Avril 1840). Annales des Sciences Naturelles, Serie 2, 13:310-319.

McKenna, M.C. \& Bell, S.K. 1997. Classification of mammals above the species level. $1^{\mathrm{a}}$ ed. New York, Columbia University Press, 631p.

Mares, M.A. \& Ojeda, R.A. 1982. Patterns of diversity and adaptation in South American Hystricognath rodents. In: M.A. Mares \& H. Genoways (eds.) Mammalian Biology in South America, Pymatuning Laboratory of Ecology, p. 393-432.

Marshall, L.G. \& Sempere, T. 1991. The Eocene to Pleistocene vertebrates of Bolivia and their stratigraphic context: a review. Revista Tecnica de Yacimientos Petroliferos Fiscales Bolivianos, 12(3-4):631-652.

Marshall, L.G.; Berta, A.; Hoffstetter, R.; Pascual, R.; Reig, O.A.; Bombin, M.; Mones, A. 1984. Mammals and Stratigraphy: geochronology of the continental mammal-bearing Quaternary of South America. Palaeovertebrata, Mémoire Extraordinaire, $1-76$.

Mentz-Ribeiro, P.A. \& Ribeiro, C.T. 1999. Escavações arqueológicas no Sítio RS-TQ-58, Montenegro, RS, Brasil. Série Documento, Arqueologia, 10:1-86.

Mentz-Ribeiro, P.A.; Klamt, S.C.; Buchaim, J.J.S. \& Ribeiro, C.T. 1989. Levantamentos arqueológicos na Encosta do Planalto entre o vale dos Rios Taquari e Caí, RS, Brasil. Revista do CEPA, 19(16):49-89.

Mones, A. \& Castiglioni, L.R. 1979. Additions to the knowledge on fossil rodents of Uruguay (Mammalia: Rodentia). Paläontologische Zeitschrift, 53(1/2):77-87.

Montalvo, C.I.; Verzi, D.H.; Vucetich, M.G. \& Visconti, G. 1998 Nuevos Eumysopinae (Rodentia, Echimyidae) de la Formación Cerro Azul (Mioceno Tardío) de La Pampa, Argentina. In: JORNADAS GEOLÓGICAS Y GEOFÍSICAS BONAERENSES, 5, 1998. Anales, Mar del Plata, p. 57-64.

Moraes-Santos, H.M.; Souza de Melo, C.C. \& Toledo, P.M. 1999. Ocorrência de Dactylomys dactylinus (Caviomorpha, Echimyidae) em material zooarqueológico da Serra dos Carajás, Pará. Boletim do Museu Paraense Emilio Goeldi, 15(2):159167.

Morrone, J.J. 2001. Biogeografía de América Latina y el Caribe. M\&T-Manuales \& Tesis SEA, 3:1-148.

Oliveira, E.V. 1992. Mamíferos Fósseis do Quaternário do Estado do Rio Grande do Sul, Brasil. Programa de Pós-Graduação em Geociências, Universidade Federal do Rio Grande do Sul, Dissertação de Mestrado, 113 p.

Oliveira, E.V. \& Lavina, E.L. 2000. Mamíferos - protagonistas dos 
tempos modernos. In: M. Holz \& L.F. De Ros (eds.) Paleontologia do Rio Grande do Sul, CIGO/UFRGS, p. 376397.

Oliveira, L.D.D.; Souza-Cunha, F.L. \& Locks, M. 1985. Um Hydrochoeridae (Mammalia, Rodentia) no Pleistoceno do nordeste do Brasil. In: D.A. Campos, C.S. Ferreira, I.M. Brito \& C.F. Viana (org.) Coletânea de Trabalhos Paleontológicos, DNPM, p. 93-97.

Patton, J.L. \& Rogers, M.A. 1983. Systematic implications of non-geographic variation in the Spiny rat genus Proechimys (Echimyidae). Zeitschrift für Säugetierkunde, 48:363-370.

Paula-Couto, C. de. 1946. Atualização da nomenclatura genérica e específica usada por Herluf Winge, em "E Museo Lundii”. Estudos Brasileiros de Geologia, 1:59-80.

Paula-Couto, C. de. 1978. Mamíferos fósseis do Pleistoceno do Espírito Santo. Anais da Academia Brasileira de Ciência, 50(3):365-379.

Queiroz, A.N. 2004. Étude des vertébrés du site archéologique RSTQ-58, Montenegro, RS, Brésil: aspects archéozoologiques et taphonomiques. BAR International Series, 1298:153-176.

Quintana, C.A. 1997. El roedor Dolicavia minuscula (Caviomorpha, Caviidae) del Plioceno Superior de la Provincia de Buenos Aires, Argentina. Historia Animalium, 3:55-71.

Reig, O.A.; Busch, C.; Ortells, M.O. \& Contreras, J.R. 1990. An overview of evolution, systematics, population biology and speciation in Ctenomys. In: E. Nuevo \& O.A. Reig (eds.) Biology of Subterranean Mammals at the Organismal and Molecular Levels. Alan R. Liss, p. 71-96.

Rodrigues, P.H. \& Ferigolo, J. 2004. Roedores Pleistocênicos da Planície Costeira do Estado do Rio Grande do Sul, Brasil. Revista Brasileira de Paleontologia, 7(2):231-238.

Rosa, A.O. 1996. Análise dos restos faunísticos do sítio arqueológico de Itapeva (RS-LN-201), Município de Torres, RS: segunda etapa de escavação. Documentos, 6:157-164.

Rosa, A.O. 2006a. Caçadores de cervídeos no litoral central: o sítio RS-LC-96. Pesquisas, Antropologia, 63:223-248.

Rosa, A.O. 2006b. Análise preliminar dos restos faunísticos do sítio RS-LC-80: uma ocupação Tupiguarani. Pesquisas, Antropologia, 63:249-258.

Salles, L.O.; Carvalho, G.S.; Weksler, M.; Sicuro, F.L.; Abreu, F.; Camardella, A.R.; Guedes, P.G.; Ávilla, L.S.; Abrantes, E.A.P.; Sahate, V. \& Costa, I.S. 1999. Fauna de Mamíferos do Quaternário de Serra da Mesa (Goiás, Brasil). Publicações Avulsas do Museu Nacional, 78:1-15.

Salles, L.O., Cartelle, C.; Guedes, P.G.; Boggiani, P.C.; Janoo, A. \& Russo, C.A.M. 2006. Quaternary mammals from Serra da Bodoquena, Mato Grosso do Sul, Brazil. Boletim do Museu Nacional, Zoologia, 521:1-12.

Schmitz, P.I.; Girelli, M. \& Rosa, A.O. 1997. Pesquisas arqueológicas em Santa Vitória do Palmar, RS. Documentos, 7:1-95.

Silva, F. 1984. Mamíferos Silvestres do Rio Grande do Sul. $1^{\mathrm{a}} \mathrm{ed}$. Porto Alegre, FZB/RS, 245 p.

Silva, G.O.S. \& Rosa, A.O. 2006. Restos faunísticos do sítio RSLC-82: uma pequena amostra. Pesquisas, Antropologia, 63:219222.

Souza-Cunha, F.L. \& Guimarães, M.L. 1978. A fauna sub-recente de vertebrados do "Grande Abrigo da Lapa Vermelha Emperaire (P.L.)" Pedro Leopoldo, Estado de Minas Gerais. Arquivos do Museu de História Natural da Universidade Federal de Minas Gerais, 3:201-238.

Souza-Cunha, F.L. \& Magalhães, R.M.M. de. 1986. A fauna de vertebrados sub-recentes de Cerca Grande, Matozinhos, Mi- nas Gerais. Publicações Avulsas do Museu Nacional, 65:119131.

Thomas, O. 1909. Notes on some South-American Mammals, with descriptions of new species. Annals and Magazine of Natural History, 8(4):230-242.

Thomas, O. 1916. Some notes on the Echimyinae. Annals and Magazine of Natural History, 8(18):294-301.

Toledo, P.M. de; Moraes-Santos, H.M. \& Souza de Melo, C.C. de. 1999a. Levantamento Preliminar de Mamíferos Não-Voadores da Serra dos Carajás: Grupos Silvestres Recentes e Zooarqueológicos. Boletim do Museu Paraense Emílio Goeldi, 15(2):141-157.

Toledo, P.M. de; Souza de Melo, C.C. de.; Moraes-Santos, H.M.; Diniz, F.M. \& Oliveira, M.F. de. 1999b. Paleoecology of the Serra dos Carajás mammalian fauna. Ciência e Cultura, 51(3/ 4):311-317.

Tonni, E.P. 1981. Pediolagus salinicola (Rodentia, Caviidae) en el Pleistoceno tardío de la Provincia de Buenos Aires. Ameghiniana, 18(3-4):123-126.

Ubilla, M.; Piñeiro, G. \& Quintana, C.A. 1999. A new extinct species of the genus Microcavia (Rodentia, Caviidae) from the Upper Pleistocene of the Northern Basin of Uruguay, with Paleobiogeographic and Paleoenvironmental Comments. Studies on Neotropical Fauna and Environment, 34:141-149.

Ubilla, M.; Oliveira, E.; Rinderknecht, A. \& Pereira, J. 2007. First record of Microcavia (Rodentia, Caviidae) in Brazil (late Pleistocene, Rio Grande do Sul). In: JORNADAS ARGENTINAS DE PALEONTOLOGIA DE VERTEBRADOS, 23, 2007. Anales, Trelew, APA, p. 34.

Verzi, D.H. 2008. Phylogeny and adaptive diversity of rodents of the family Ctenomyidae (Caviomorpha): delimiting lineages and genera in the fossil record. Journal of Zoology, 274:386-394.

Verzi, D.H. \& Olivares, A.I. 2006. Craniomandibular joint in South American burrowing rodents (Ctenomyidae): adaptations and constraints related to a specialized mandibular position in digging. Journal of Zoology, 270:488-501.

Verzi, D.H.; Vucetich, M.G. \& Montalvo, C.I. 1994. Octodontidlike Echimyidae (Rodentia): an upper Miocene episode in the radiation of the family. Palaeovertebrata, 23(1-4):199-210.

Verzi, D.H.; Vucetich, M.G. \& Montalvo, C.I. 1995. Un Nuevo Eumysopinae (Rodentia, Echimyidae) del Mioceno tardío de la Provincia de La Pampa y consideraciones sobre la historia de la subfamilia. Ameghiniana, 32(2):191-195.

Verzi, D.H.; Tonni, E.P.; Scaglia, O.A.; San Cristóbal, J.O. 2002. The fossil record of the desert-adapted South American rodent Tympanoctomys (Rodentia, Octodontidae). Paleoenvironmental and biogeographic significance. Palaeogeography, Palaeoclimatology, Palaeoecology, 179:149-158.

Vucetich, M.G. \& Verzi, D.H. 1996. Un nuevo Eumysopinae (Rodentia, Echimyidae) de la "Formación" Irene (Chapadmalalense inferi-or?) y la diversidad de la subfamilia. In: JORNADAS GEOLÓGICAS Y GEOFÍSICAS BONAERENSES, 4, 1996. Actas, Junín, p. 15-22.

Vucetich, M.G. \& Verzi, D.H. 1999. Changes in diversity and distribution of the Caviomorph rodents during the late Cenozoic in Southern South America. Quaternary of South America and Antartic Peninsula, 12:207-224.

Vucetich, M.G. \& Verzi, D.H. 2002. First record of Dasyproctidae (Rodentia) in the Pleistocene of Argentina. Paleoclimatic implication. Palaeogeography, Palaeoclimatology, Palaeoecology, 178:67-73.

Vucetich, M.G.; Verzi, D.H. \& Tonni, E.P. 1997. Paleoclimatic 
implications of the presence of Clyomys (Rodentia, Echimyidae) in the Pleistocene of central Argentina. Palaeogeography, Palaeoclimatology, Palaeoecology, 128:207-214.

Vucetich, M.G.; Verzi, D.H. \& Hartenberger, J.L. 1999. Review and analysis of the radiation of the South American Hystricognathi (Mammalia, Rodentia). Comptes Rendus de l'Académie des Sciences Paris, Sciences de la Terre et des Planètes, 329:763-769.

Ximenez, A. 1980. Notas sobre el genero Cavia Pallas con la descripción de Cavia magna sp.n. (Mammalia - Caviidae). Revista Nordestina de Biologia, 3:145-179.

Werdelin, L. 1991. Pleistocene vertebrates from Tarija, Bolivia in the collection of the Swedish Museum of Natural History. Revista Tecnica de Yacimientos Petroliferos Fiscales Bolivianos, 12(3-4):673-684.

Winge, H. 1888. Jordfundne og nulevende Gnavere (Rodentia) fra Lagoa Santa, Minas Geraes, Brasilien. E Museo Lundii, 1:1200.

Winge, H. 1941. The interrelationships of the mammalian genera, Rodentia, Carnivora, Primates (trans. from Danish by E. Deichmann and G.M. Allen), Copenhagen, Reitzels Forlag, 376 p.

Woods, C.A. \& Howland, E.B. 1979. Adaptive radiation of Capromyid rodents: anatomy of the masticatory apparatus. Journal of Mammalogy, 60(1):95-116.

Woods \& Kilpatrick, 2005. Infraorder Hystricognathi Brandt, 1855. In: D.E. Wilson \& D.M. Reeder (eds.) Mammal species of the world: a taxonomic and geographic reference, Johns Hopkins University Press, p. 1538-1600.

Received in April, 2008 ; accepted in July, 2008.
Appendix. Comparative material examined in this study: Cavia aperea, MCN-M 038, MCN-M 184, MCN-M 186, MCN-M 188, MCN-M 264, MCN-M 2818, MCN-M 2819; Cavia fulgida, MCN-M 386, 387; Cavia magna, MCN-M 222, 303, 304; Clyomys sp., MLP 91.IV.25.116 MLP 91.IV.25.135, MLP 91.IV.25.171; Clyomys bishopi, MN 43071 , MN 43074, 68970; Clyomys laticeps, MN 31547, MN 31548, MN 31549, MN 31550, MN 31551; MZUSP 25880, MZUSP 25907, MZUSP 26660, MZUSP 26765; Dicolpomys fossor, ZMUC mandible 1, 2, 3, 4, 5 (Lund collection in Winge, 1888); Euryzygomatomys mordax ZMUC skull 1 (Lund collection in Winge, 1888); Euryzygomatomys spinosus, MCN-M 2364; MN 1984, MN 4029, MN 7284, MN 31519; Kannabateomys amblyonyx, MCN-M 1320; Phyllomys blainvillei, MN 1345, MN 1350, MN 1512, MN 21512; Phyllomys dasythrix, MCN-M 044, MCN-M 046, MCN-M 047, MCN-M 048; Phyllomys lamarum, MN 11259, MN 21654, MN 21664; Phyllomys medius, MCN-M 391; Thrichomys sp., MN 29126, MN 29128, MN 29140, MN 42191, MN 42192. 